MARRIED WOMEN'S PROPERTY LAW IN NINETEENTH-CENTURY VIRGINIA

Sara Frances Ketchum

Charlottesville, Virginia

B.A., Yale University, 1979

A Thesis Presented to the Graduate Faculty of the University of Virginia

in Candidacy for the Degree of Master of Arts

Corcoran Department of History

University of Virginia

August, 1985

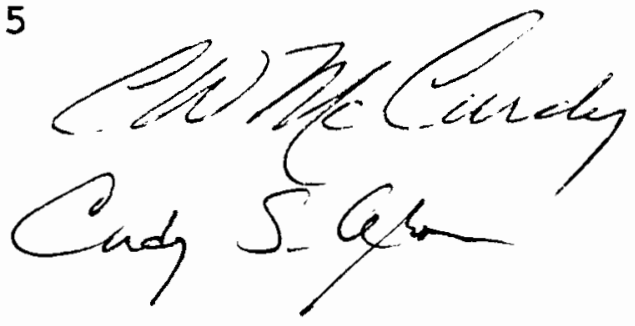


TABLE OF CONTENTS

Section

Page

Introduction. ...............................

The Eeme covert................................

Passage of the 1877 Virginia Married Women's Property Act...l

A. Resistance, 1848-1870.......................11

B. Breakdown of Resistance, 1870-1877.............22

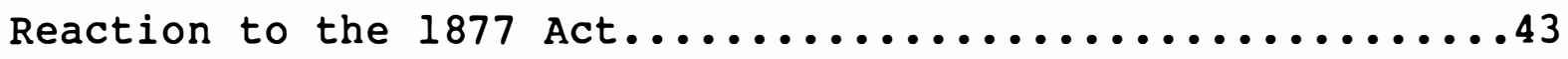

Litigation and Construction, 1877-1888.............61

The 1887 Code, the 1890's and the Act of $1900 \ldots \ldots \ldots \ldots . . .76$

A Separate Identity.............................92

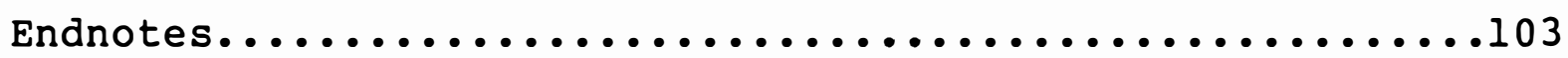

Bibliography..............................115 
INTRODUCTION.

During the course of the nineteenth century, state legislatures one by one enacted measures to relieve married women of their common law disabilities regarding property ownership. Under the common law, a wife surrendered ownership of her personal estate and control of her real estate upon marriage. The state of Virginia, "whenever hastening, hastening slowly," was the last state to pass a married women's property act. In recent studies of the married women's legislation, historians have argued convincingly that the acts were not signs of a revolution in women's rights, but were instead limited in purpose and effect. ${ }^{l}$ An examination of the 1877 measure passed in Virginia, construction of the act by the courts, and legislative changes embodied in an 1887 Code revision and a 1900 statute, corroborates the findings of other historians that legal rights for married women came slowly and hesistantly. Nevertheless, the significant changes in married women's law in Virginia between 1877 and 1900 must not be underemphasized. In the course of twenty-three years, the Virginia General Assembly did away with nearly all of the common law restrictions governing a wife's possession and control of her property.

This essay will explore the reasons for the passage of a married women's property law in Virginia, and will examine reaction to the act and subsequent legislation and court rulings up to the act of 1900. The essay presents three major 
arguments. First, the 1877 statute passed in Virginia because of a convergence of motivations among legislators. For some, the act represented a debt relief measure, for others, an amendment to the harsh rules of coverture, and for still others the law was a symbol of Virginia's progress toward a new era. Second, reactions to the act, especially those of Virginia lawyers, reflected attitudes about the measure's implications -- its departure from the common law, its promise of transforming the position of married women, and its significance as a symbol of the "New South." Finally, while subsequent legislation and court cases regarding married women's property law assumed no specific pattern, the ultimate outcome of the confused course of the law was a legal recognition of the separate identity of the wife, and consequently, a major step forward for married women in Virginia. 


\section{THE FEME COVERT}

Before the enactment of married woman's property laws in the mid-nineteenth century, wives in Virginia and all other common law states in America shared the legal status of feme covert. Their position, known as coverture, was an element of the English common law adopted by the American colonies. Coverture meant in effect that upon marriage, a woman's legal identity became subsumed under that of her husband, and she thereby lost most of her legal rights. She surrendered ownership of her personal property and control of her real estate to her husband: while he could not devise or alien her real property, he had unrestricted use of the property's rents and profits. In addition, the husband had the right to reduce the wife's choses in action into possession. Because a married women had no separate status in the eyes of the law, she was deprived of the ability to make a contract or will, and to sue or be sued unless joined by her husband. And because under the common law the husband and wife were considered a single unit, the married couple could not give evidence for or against each other in court.

The common law afforded the feme covert some protection in return for her loss of legal status. By theory, and usually in practice, the husband supported his wife and their children during coverture. He was also responsible for his spouse's torts and her antenuptial debts and contracts. If the husband predeceased his wife, she received a one-third 
life interest in the family's real property, called dower, upon his death. Unless the husband chose to give his wife more by will, however, she was limited to this one third interest no matter what proportion of the couple's property had been hers before marriage. A widow could also claim one-third of her spouse's personalty in absolute ownership, subject to his debts. If the wife predeceased her husband, and if the couple had a child born alive, the husband was entitled to a life interest in his wife's estate, or curtesy. 2 An ancillary system of law grew up alongside the common law in England which mitigated some of the strictures of coverture. Called equity, this legal system offered remedies where none existed at common law. Equity developed slowly, but by the eighteenth century a wife who owned property was able to exert some control over her estate through an equitable marriage settlement or the creation of an equitable separate estate. The wife's powers were limited by the terms of the equitable instrument, however, and equity required that she act through a trustee. The establishment and administration of a separate equitable estate was complicated and expensive, and thus only wealthier women generally had access to equity courts. ${ }^{3}$ And the legal exceptions to coverture did little to alter traditional assumptions about women's inferior position which underlay the common law. As Linda Kerber explains: "Coverture was based on the assumption that married women had neither independent minds nor independent power .... [and] it drew its strength ... from an 
ancient Western political tradition that defined all women as politically and legally irresponsible." 4

American colonists brought the common law with them from England, but there is considerable controversy about how strictly the rules of coverture were enforced in the colonial and early Republican eras. Most historians agree that before the middle of the eighteenth century, married women in America enjoyed a comparative amount of legal freedom. This relaxation of rules was due to varying conditions in the colonies, including the presence of religious and non-English influences, independent initiatives by local legislatures, and a shortage of labor which allowed wives a greater economic role. Records exist of married women acting as independent businesswomen or "sole traders," obtaining land grants, and exercising unfettered control over their property. As the colonies developed, however, Americans followed English common law practices more closely and the legal status of married women consequently deteriorated. 5

Some historians maintain that this deterioration continued after the American Revolution and into the nineteenth century. There is new evidence, however, that after 1800 state legislatures began to enact probate reform laws and other measures which recognized women's economic role within the family. This legislation has been linked to the rise of the "cult of domesticity," which embraced the notion of woman's moral superiority and intellectual inferiority, limiting her orbit to the home. 6 The exceptions early 
nineteenth-century Americans made in the law of coverture were undoubtedly limited. Equity continued to offer relief to the wealthy feme covert, but in many states equity courts were poorly developed or nonexistent. 7

Beginning in the $1830^{\prime} \mathrm{s}$, state legislatures launched a frontal attack on coverture. One state after another enacted married women's property statutes designed to relieve married women of at least some of their common law disabilities regarding property. By 1850 , twenty-three states had passed some form of married women's law. These measures varied from state to state, but most operated to protect a wife's property from the debts of her husband, and granted married women a voice in the control and disposition of their estates.

Historians have yet to provide a complete explanation of the cause of this wave of legislation in the antebellum United States. They have only recently begun to explore the subject in depth, and just a handful of detailed studies are available. The New York married women's statute of 1848 has received the most attention to date, most likely because of the wealth of evidence about the New York law and the importance of New York state as locus of both legal and feminist reform. The New York act provided that all real and personal property of a woman who thereafter married would remain her separate property, and would not be subject to her husband's control. It further provided that the real and personal property of a woman married at the time of the passage of the act would become her separate property, and 
would also be free from her husband's control. 8 While scholars disagree about the reasons for the law's passage, all maintain that feminist motives were not foremost in legislators' minds.

In a 1972 law review article about the act, John Johnston suggests that the New York legislature enacted the law to ease alienation of property and to abolish cumbersome forms of common law. He writes: "Legislative changes in favor of married women were probably only one aspect of the general release of economic energy that dominated nineteenth century legal development. ${ }^{9}$ In a more detailed study of the New York statute, Peggy Rabkin claims that a number of influences led to its enactment. Like Johnston, Rabkin links the act to a general legislative response in New York to a growing commercial economy. She specifically connects the act to the contemporary codification movement, which sought to reform the common law, and among other things, to defeudalize property law in New York. Rabkin also notes that equity was merged with the common law in New York in 1847, and contends that the New York married women's act was passed in part as a replacement for the protection which equity provided to family property. 10

Norma Basch's recent work, In the Eyes of the Iawe adds to Johnston's and Rabkin's studies and provides the most complete and convincing explanation of the passage of the New York statute. Like Rabkin, Basch asks why overwhelmingly nonfeminist legislators were willing to make a dramatic change 
in the law for married women. Basch maintains that the act passed not because of a single influence, but because of a "confluence of interests" which together provided the bill enough support to pass. Some legislators favored the bill because it served as a debt relief measure. By giving wives control of their property, the Act shielded some of the family's property from a husband's debts. Basch notes that the 1848 act and a subsequent married women's law of 1860 were passed in the wake of economic panics, and that a variety of other debt relief measures were enacted during the same period. She argues that other legislators favored the bill because they were truly concerned about alleviating the common law restrictions governing married women. And finally, as Rabkin and Johnston also contend, Basch claims that some legislators saw the act as another inroad against the feudal, cumbersome practices of the common law, which were unsuited to an expanding economy. She also links the passage of the act to the legal reform movement, which criticized the common law and undermined equity. 11

No studies comparable to Basch's exist for other married women's statutes, so it is difficult to determine whether the same influences led to the passage of the laws in other states. An article by Richard Chused about the married women's property acts suggests that there were common trends. Chused too finds a connection between debt relief legislation and the married women's acts. He also proposes that some legislators favored the acts because they objected to the 
harsh effects of coverture. Unlike Basch, however, Chused claims that the acts were a response to wives' growing influence within the family, and finds that other measures chipping away at coverture (such as laws governing divorce, abandoned wives and child custody) were passed during the same period. Chused also agrees with Rabkin and Basch that in New York the married women's law can be linked to law reform, although he suggests that this might not hold true in other states. 12

While the married women's property acts do not seem to have been prompted by feminist impulses, legislators were not unaware of the threat the acts posed to the legal fiction of marital unity. As Basch notes: "To wipe out all that was paternalistic in the old legal relationship of baron and feme was to destroy the legal foundation of the wife's economic dependence, one source of her relegation to the domestic sphere."13 Most of the initial married women's property acts did only the minimum required to protect a women's property from being completely squandered by her husband. It took several decades for most states to grant women more complete power over their property, such as control of their wages and ability to contract and sue as a single woman, or feme sole. 14 Married women's acts also lost much of their potential power to relieve wives of the disabilities of coverture through narrow rulings in the courts. Judges construed the statutes strictly primarily because the acts were in derogation of the common law, although some historians have suggested that 
antifeminist feelings also prompted judges to take the teeth out of the married women's acts. 15

Despite the feminist implications of the acts and their innovative nature, most states in the slaveholding south passed some form of married woman's property legislation before 1860. In fact, Arkansas in 1835 was the first state to pass such legislation, followed by Mississippi in 1839, Maryland in 1843, Florida and Texas in 1845, Alabama and Rentucky in 1846, North Carolina in 1849, and Tennessee in 1850. (Louisiana used a civil law system, which allowed wives in the state to own and control property. ${ }^{16}$ ) Chused notes that these statutes almost without exception operated only to exempt a wife's land and/or slaves from her husband's debts. 17 Nevertheless, three Southern states, North Carolina, South Carolina, and Virginia, did not pass even a limited married women's bill until after the Civil War. 
II. RASSAGE OE THE_1877_VIRGINIA_MARRIED_WOMEN'S_RRORERTY_ACT

\section{A. Resistance, $1848-1870$}

In the years that other legislatures were enacting married women's property legislation, the Virginia General Assembly displayed a particularly stubborn resistance to passing a similar law. Even during Reconstruction, when the two other Southern holdouts -- Georgia and South Carolina -at last approved married women's bills, Virginia refused to budge. The evidence is scarce, but it seems likely that Virginia legislators opposed enactment of a married women's bill because of attitudes about debt relief, the common law, and the proper role of married women.

Although Virginia did not support a married women's law before the Civil War, the Commonwealth's legislators were not unaware of the acts being passed in other states. The subject of reform in married women's property law was first raised in the Virginia General Assembly during the 1848-49 session. Proposals to change Virginia law relating to coverture came up in this session on four separate occasions. (While there is no direct evidence of a connection, it is probably not coincidental that Virginia began to debate the issue at the same time that the New York legislature was enacting a married women's law.) In December of 1848, Mr. Joseph Harvey of Westmoreland County introduced a resolution in the House of 
Delegates calling for the Committee for the Courts of Justice to consider exempting a married woman's property from the preand postnuptial debts of her husband. 18 several months later, Mr. Harvey introduced a bill in the House to "protect the property rights of married women." The House referred the bill to committee, where it was apparently dropped. 19

In July of 1849 , the House appointed a select committee to consider the feasibility of enacting some form of married women's law. 20 The special committee drafted a bill which was very much like the act passed in Mississippi in 1839, and thus limited in effect. It provided that the slaves of a wife would continue to be her property, although the husband would have control of them, and further stipulated that the wife's and husband's property would not be liable for the antenuptial debts of the other. The bill was clearly designed to be a debt relief measure. 21 House members promptly tabled the committee bill.22 Not giving up, the chairman of the select committee, Charles Faulkner of Berkeley County, proposed an amendment to the new Virginia code "for the further protection of married women" at the end of the legislative session. This measure was also dropped. 23

Legislative debates are not available for this session, but a lengthy editorial about the select committee's measure in the Richmond Whig suggests reasons for the General Assembly's refusal to pass a married women's bill. Despite the committee bill's narrow provisions, the Whig's editor was vehemently opposed to it. He expressed fear that the bill 
would subvert the institution of marriage, and would transform the gentle ladies of Virginia into mercenary and aggressive businesswomen. The editor also claimed that the bill would encourage fraud, and that there was no popular call for it. Finally, he argued that common law ought not to be tampered with, particularly in regard to conjugal relations, and warned against innovation in general. He wrote:

With respect to this new movement -- this touch of Red Republicanism -- this invasion of the family circle -this interference between man and wife - between the father and his children -- which annihilates that salutary subordination of the one sex to the other, which has made American and English women the purest specimens of humanity -- we invoke our Legislators to pause.

The Whig article also reported the House debates on the committee's bill. Judging from their comments, Virginia legislators were apparently opposed to the bill for most of the same reasons as the Whig's editor. A few other objections were raised: one delegate stated that the bill did not protect married women adequately, and another argued that it benefitted only the wealthy and those who owned slaves. 24 In spite of the charges of a few legislators that the proposed married women's bill was antidemocratic, more likely the principal reasons for the Virginia legislators' disfavor were the obverse of the reasons for the New York legislators' support of a married women's property bill. First, Virginia was among the most restrictive states in regard to debt relief legislation. As Peter Coleman has noted: "Over the span of some 250 years from the beginnings of settlement to the 
opening of the twentieth century, a conservative attachment to traditional legal principles and a slow pace of change characterized relationships between lenders and borrowers in Virginia."25 Virginia did not abolish imprisonment for debt until well after the Civil War, and never allowed debts to be discharged through bankruptcy proceedings. While the Commonwealth did pass some relief measures following the economic depression of the late $1830^{\prime} \mathrm{s}$, this legislation in no way matched the extent of debt relief legislation in New York state which Basch details. 26 A callous remark made by the editor of the Bichmond Whig reveals an attitude about debt probably shared by other Virginians, and suggests why a married women's law would not find support in Virginia even as a relief measure. Responding to an argument in favor of the bill that it would protect those women who were married to thriftless husbands, the editor asked: "But is that not her own fault -- and is it not better that the individual should expiate her own wrong, than that the whole of society be made to suffer from it?n 27

If Virginians found no need for other measures protecting family property from creditors, then it is doubtful that they would support a married women's property measure which promised debt relief but also threatened to abrogate the rules of coverture. Throughout the 1800's, the Commonwealth clung to common law traditions, and resisted any movement toward reform of the common law. In fact, the nineteenth-century Virginia bar seemed to thrive on the arcane practices and 
pleadings of the common law, and resisted the movement to codify even civil procedure well into the twentieth century. 28 Substantive reforms of common law came slowly as well. Bertram Wyatt-Brown claims that the common law was "most appealing in a South that honored tradition, loved the forms of deference that the law and courts exemplified, and, with other intellectual avenues closed, used the law to combine intellectual and social utility in a conservative setting." 29 Equity, which also flourished in nineteenth-century Virginia, provided all the protection of married women's property that the Commonwealth's lawmakers were prepared to extend. (Notably, the state of Mississippi, which passed a married women's law in 1839, did not have an equity system.) While no statewide study has been conducted on the use of equity in antebellum Virginia, suzanne Lebsock has found in a remarkable study of prewar Petersburg that citizens of the city created nearly 600 equitable estates for married women between 1821 and $1860 .^{30}$ Lebsock believes that a large majority of these estates were intended to shield family property from debt, particularly because few granted wives any substantial control of their property. ${ }^{31}$ Thus there was in antebellum Virginia neither an assault on common law which historians suggest was linked to the passage of a married women's bill in New York, nor an attack on equity which led to a search for adequate replacement of the equitable separate estate.

Basch writes that "the instability of the antebellum 
economy, the inequities of the legal system, and ... the woman question" led to the passage of a married women's property statute in New York. 32 Virginia legislators were clearly opposed to legislation addressing the first two of these concerns. Were they also opposed to the married women's bill because of its threat to the dependent position of wives in the state? The rhetoric of legislators and the editor of the Whig would imply as much, but legislators in states both North and South issued similar warnings which did not prevent bills from being passed. 33 It is possible, however, that Virginia defended the ideal of Southern womanhood more vehemently than other states and thus resisted any assaults on the myth.

Recent studies have helped to discredit the notion that the weak, innocent and retiring southern belle actually existed. 34 suzanne Lebsock's work on Petersburg, for example, reveals that antebellum Virginia women, married and single, were active, assertive, and increasingly autonomous, especially within the home. Lebsock also notes legal improvements for married women, represented in divorce reform statutes enacted in 1827, 1848, and 1853, which increased the number of causes which were grounds for complete divorce. Virginia law also allowed a married women to renounce her husband's will and accept the share she would receive if he had died intestate. 35 The Virginia General Assembly enacted other legislation which recognized married women's active role within the family. As early as 1831, a law was enacted stating that the consent of the mother was sufficient in the 
marriage of a minor child where no father or guardian was present. 36 An act passed in 1846 incorporating an orphan asylum recognized that women were taking a public role in organizations by stipulating that "the husband of any married women, who is or may be a member or officer of the said association, shall not be liable to the said association for any loss occasioned by the neglect or misfeasance ... or upon any subscription or engagement of his wife." 37 Legislation was also introduced in the $1850^{\prime} \mathrm{s}$ to allow a wife to take out an insurance policy on her husband's life. 38

The Virginia General Assembly was willing to pass certain laws ameliorating the legal condition of married women, but it certainly did not go too far. Given the evidence Lebsock presents, the legislature's failure to travel further to ease the harshness of coverture could not have been due to a fear of destroying the submissive wife, for she was largely an illusion. Their resistance is more likely due to a fear of destroying the myth. As Ann Firor Scott argues, the ideal was particularly compelling in the antebellum south, faced with Northern bombardment of its social structure: ${ }^{39}$

The persistence of the complementary images of the soft, submissive, perfect woman and of the strong, commanding, intelligent, and dominant man in the face of an exigent reality that often called for quite different qualities suggests that these images had deep significance for the men and women who believed in them. A society increasingly threatened from the outside had every reason to try to diminish internal threats to its stability. George Fitzhugh made this quite explicit when he equated any change in the role of women of in the institution of slavery with the downfall of the family and the consequent demise of society. 
The defense of Southern ideals, which became more entrenched as attacks became more strident, may in part explain a phenomenon Lebsock notes occuring in the 1850's. She found that during this decade, Petersburg men forced women out of the public sphere and took over their public functions. 40 It seems probable that in Virginia resistance to married women's acts and to women taking an active public role sprung from the same impulse to defend Southern institutions. Not surprisingly, the two other Southern states which opposed married women's property acts before the Civil War, South Carolina and Georgia, were also highly conservative eastern seaboard states. Thus men of Virginia clung to the ideal of Southern womanhood, to the point of believing that their wives could not possibly favor legislation granting them legal rights. The Whig's editor wrote: 41

A woman of heart loves devotedly enough to stake her all upon the man she loves .... Such women do not wish the Legislature to erect a barrier between them and those they love.... [T] They prefer, with the instinctive sweetness of women's nature, to lean upon the arm of affection, and to trust it for their support.

Following the session of 1848-9, Virginia legislators were for the most part silent regarding the issue of married women's property law until after the Civil War. 42 In the state's Reconstruction Constitutional Convention, which met in 1867 and 1868, delegates introduced two separate resolutions on married women's property reform. Henry Bowden, a radical Republican, proposed the first of these resolutions on December 10,1867 , soon after the start of the Convention. He 
asked that the Committee on Limitations and Guarantees investigate the expediency of a consitutional provision to secure "the rights of property, and enlarg[e] the civil capacities of married women." The Convention referred Bowden's resolution to Committee. 43 The next month, Gaston Curtiss, another Republican, introduced a second married women's resolution which read in part:

... The property and pecuniary rights of every married woman, at the time of marriage, or afterwards, acquired by gift, devise or inheritance, shall not be subject to, or liable for, the debts or contracts of the husband, and laws shall be passed providing for the registration of the wife's property.

This measure was also referred to the Committee on Limitations and Guarantees. 44

It remains a mystery why Bowden and Curtiss in particular introduced married women's property resolutions. There was apparently no cooperation between the two men: one newspaper in fact reported that Bowden had called Curtiss "a damned scoundrel."45 Bowden was a native Virginian who voted with the radicals on all major measures except school integration. 46 His resolution appears more liberal and general in its provisions than Curtiss's; he may have proposed the measure to advance women's rights. Curtiss was a New Yorker, and apparently a radical as well. He had been a member of the New York legislature, and thus was probably familiar with the workings of the New York married women's act. 47 His resolution was clearly a debt relief measure. The Committee on Limitations and Guarantees must have 
considered seriously the two married women's property resolutions, for it reported out a lengthy and highly detailed bill. The Committee's measure provided that all women who married after the adoption of the Constitution would have complete ownership of their property and exercise all rights over it as a feme sole. The bill also provided that the husband would not be responsible for his wife's debts. It protected dower, and stipulated that upon the death intestate of either spouse, the other would inherit the estate if no children had been born. 48 This bill was a considerable expansion of Curtiss's measure, and although the Committee's intention is not evident, its draft operated to give married women substantial property rights. Unfortunately, there is no record of debate on the measure, but the Richmend Dispatch reported that the Convention voted to lay it on the table, 54 to 38.49 No further married women's legislation was proposed during the life of the Convention.

The Virginia Convention's failure to enact a married women's property measure is surprising in light of the fact that Reconstruction conventions in each of the other nine Confederate states did incorporate a married women's clause in their constitutions. The measures met with little opposition, even in Georgia and South Carolina. 50 In an article about the Reconstruction acts, Suzanne Lebsock contends that the Southern conventions supported the bills because of "chivalry, of familial self-interest, and of hard times." 51 The chivalrous arguments of southerners claiming to favor the 
bills because they would shield married women from profligates and scoundrels can probably be dismissed as rhetoric. Yet it seems likely, as Lebsock contends, that the bills were in large part a response to the economic conditions in the postwar South: Southerners supported the acts because in a time of widespread debt they would protect some family property from creditors. This purpose is made clear not only in the debates of delegates favoring the acts, but also by the fact that the measures were coupled with homestead exemption clauses in several states. 52 As with antebellum acts, however, the Reconstruction measures did little to upset the assumptions about female inferiority underlying the laws of coverture. Thus the conventions could favor reform in married women's property rights while dismissing or ignoring calls for women's suffrage. 53

There is no obvious answer as to why Virginia did not respond like her sister states and include a married women's property provision in the Reconstruction Constitution. A major reason may be that the Virginia Constitutional Convention was more conservative than its counterparts, especially regarding debt relief. The same terrible economic conditions existed in Virginia as in other southern states, and the Commonwealth suffered more physical destruction than any other state during the war. 54 Yet while the virginia Convention did favor a homestead provision exempting up to $\$ 2,000$ of a debtor's property from creditors, it refused to pass any stay laws, and included a provision in the 
Constitution forbidding future stay laws. And while other conservative states like Georgia abolished imprisonment for debt, the law remained intact in Virginia. 55

It is also likely that Virginians still held the same objections to married women's statutes which were voiced in 1849 -- the bill would encourage fraud, it would destroy marital relations and a wife's gentility, and it abrogated established tenets of the common law. The fact that the Virginia Constitutional Convention was made up of a fairly high percentage of white southerners (56.38 according to one estimate) might have made it more resistant to innovation. 56

\section{B. Breakdown of Resistance, 1870-1877.}

Soon after the Conservative Party "redeemed" Virginia from Reconstruction rule in 1870, there was a sudden and concerted push among legislators in the state's General Assembly to pass a married woman's act. Seventeen bills and resolutions regarding married women's property rights were introduced in the Virginia House and Senate between 1870 and 1877, when a comprehensive married women's law was finally enacted. These bills and resolutions varied from simple debt relief measures to more broadly-framed measures granting women considerable control of their property. Most of the measures met with stiff opposition in the Committee for the Courts of Justice, but several advanced through second or third 
readings. One bill "securing to married women all property acquired by them before, or after marriage" actually passed the Senate on April 10, 1874, but soon died in the House. 57

In 1875, the General Assembly passed an initial married women's property act. This law provided that the real and personal property of a wife, and the rents and profits from the estate which she owned at the time of marriage or which she acquired after marriage from any source other than her husband, would not be liable for the antenuptial debts of her husband. It also stated that while a suit could be maintained against the husband and wife jointly for her antenuptial obligations, only the property of the wife would be subject to judgment. 58

The 1875 law was originally introduced in the senate by Charles T. Smith of Nelson County. Senator Smith had sponsored several other bills on married woman's property rights in the senate, some similar to the 1875 act and others more general in effect. On a few occasions, he introduced two measures concurrently, perhaps in the hope that if the members rejected the more liberal proposal they would accept a limited bill. As Smith later remarked, the 1875 statute met with "formidable opposition," but it travelled an easier path through the Senate than previous bills. The senate passed the measure on December 11,1874 by a vote of 16 to 14 . The House then amended the bill and passed the amended version by a vote of 80 to 18.59

Smith claimed that the 1875 law paved the way for the 
broader 1877 married women's act, and indeed, it is probable that this first inroad against the strictures of coverture made further incursions easier. It was Smith who first introduced the 1877 legislation on December 22, 1876 . Although the bill went in and out of Committee and was amended several times, it had a relatively smooth passage through the Senate and was adopted by a vote of 21 to 7 on March 9, 1877 . The House passed the bill on April 3, 1877 by a vote of 59 to 38, and it was signed into law on April 4, 1877.60

Like initial married women's acts in other states, the Virginia married women's statute or "Smith Act" was limited in effect. It provided that all real and personal property owned by a woman who thereafter married would continue to be her separate estate, and not liable for the debts or subject to the disposal of her husband. The bill also stated that any property acquired by a married woman as a sole trader would remain hers. A woman who was married at the time of enactment would gain control of the property she thereafter acquired by "gift, grant, purchase, inheritance, devise or bequest." The act limited a wife's power over her newly-acquired estate, however, by requiring that she could only contract "in relation to" her separate estate, and that her husband had to join in these contracts unless they regarded property she had acquired as a sole trader. The act also stipulated that the husband must join in all suits by or against his wife. A woman whose husband might refuse to join in a suit or contract was protected under the third section of the act, which 
provided her an equitable remedy in such circumstances. 61

Despite the Smith Act's limitations, it represented a dramatic departure from the restrictions of the common law. A wife could now control the rents and profits of her estate, and contract and sue, albeit to a limited extent. Given the prolonged opposition to earlier married women's legislation proposed in the Virginia General Assembly, it is difficult to explain why a law was finally enacted. Material is unfortunately scant about the passage of the bill. The debates of the General Assembly were not published at the time, and bills, committee reports, and petitions are not available. In addition, there was almost no public reaction to the law; therefore, Virginia newspapers provide little useful material. And with the exception of Charles Smith, whose lengthy speech before the senate in favor of the act was published as a pamphlet, Virginia legislators left no record of their reasons for accepting or rejecting the measure.

The Smith Act does not appear to be a political measure. The Conservative party dominated the Virginia General Assembly during the $1870^{\prime} \mathrm{s}$, and Smith was a Conservative, but the votes were not along party lines. Nor is there any noticeable correlation between geographic regions and voting patterns (see Figures 1-4). Basch found this to be true of New York as well, suggesting that a variety of motivations prompted legislators to favor the bill. 62

Studies of married women's acts passed in other states, particularly the work of Richard Chused and Norma Basch, 
$\square=$ NOES

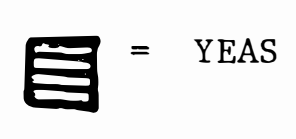

FIGURE 1 - SENATE VOTE, 1875 ACT 
$C=$ NOES<smiles>C#CC#CCCCCCCCC</smiles>

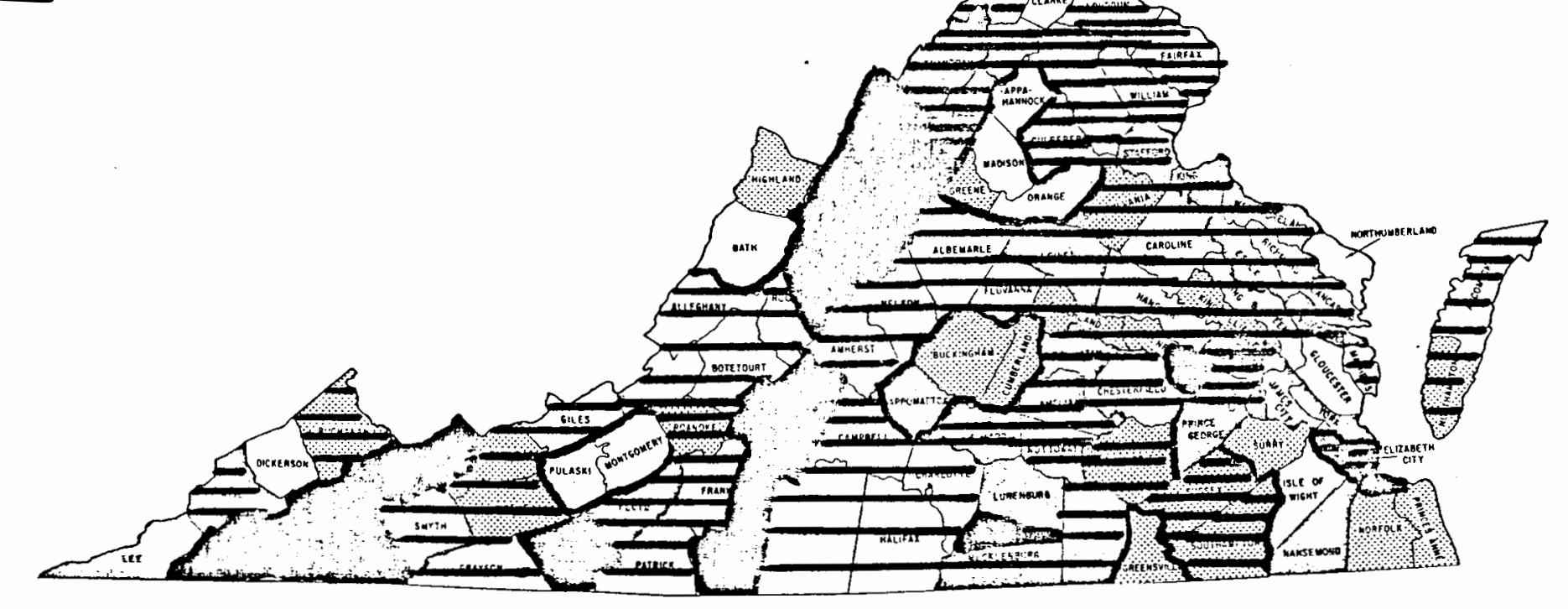

FIGURE 2 - HOUSE VOTE, 1875 ACT 
$=$ NOES

$$
\text { 目- rus }
$$

FIGURE 3 - SENATE VOTE, 1877 ACT 
ลิ

$$
\begin{aligned}
& \text { KEY }=\text { NOES } \\
& =\text { YEAS }
\end{aligned}
$$

FIGURE 4 - HOUSE VOTE, 1877 ACT 
provide some clues in determining why the married women's act passed when it did in Virginia. Evidence reveals that Virginians' attitudes about debt relief, women, and innovation in general were changing in the post-Civil War period, and thus it seems likely that as in New York state, the Virginia act was passed because of a "confluence of interests" reflecting these changing attitudes.

There is little doubt that the 1877 legislation was in part intended to be a debt relief measure. The connections between debt relief legislation and the married women's acts noted by Basch, Chused and Lebsock -- rhetoric about protection of women, other relief laws passed during the same time period - are apparent in Virginia as well. Smith's speech in favor of the married women's law is full of references to protecting married women from the vagaries of the economy. He explained to his fellow senate members that "for the many unfortunate victims among the better class of women, this law will be a princely armor, while for the thousands of our laboring females it will be a shield, ornamental in domestic peace and impenetrable in time of trouble." 63

While the Virginia Constitutional Convention had treated debtors with little sympathy, in the 1870's the General Assembly began to make concessions to debt-ridden Virginians. In 1870, the legislature passed a debt relief measure "to regulate judicial sales and prevent the sacrifice of property," and in 1871 enacted a law "to prevent the sacrifice 
of personal property at forced sales." 64 The General Assembly also attempted to enforce the provisions of the homestead exemption, which had met with opposition in lower courts and was finally declared unconstitutional by the Virginia supreme Court of Appeals in 1872.65 An 1871 act provided that until the Court of Appeals ruled on the issue, sales of property were suspended for any judgment on a debt. 66 In 1873 , legislation was enacted which exempted from creditors up to $\$ 50$ a month of a householder's wages. 67 And in 1873, imprisonment for debt was finally abolished in Virginia. 68 Later legislation included an 1877 act which declared that any lien placed by a parent or husband on exempt property would be void, and an 1878 law exempting articles of a farmer's personal property from creditors. 69

Why there was a change in attitude about debt relief among Virginia legislators after 1870 is not entirely clear. The change may be due to the fact that the distress stemming from the war and the speculation and bust of the 1870's made times particularly bad, and that literally everyone was affected, not just imprudent or reckless investors. Virginia's agricultural business was especially hard hit. Reduced acreage, coupled with competition from the West, new labor costs because of emancipation, and disastrous weather conditions prevented Virginia farmers from getting back on their feet until the 1880's. Other Virginians were hurt as old sources of collateral were wiped out: land prices fell, slaves were freed without compensation, and savings had been 
converted into worthless Confederate dollars. In addition, lack of hard currency forced up the price of money and raised interest rates. A major result was widespread debt. 70 Petitions for debt relief flooded the legislature, and one historian notes that "[a]lmost without exception every collection of contemporary letters contains references to debts owed and owing." 71

The fact that perhaps more than ever before, the innocent and honest suffered from economic distress led to a softening of the traditional Virginia stance about honoring debts. One legislator observed in a resolution for relief of the debtor class that the war's destruction had produced "great embarrassment and distress, even amongst the most prudent and provident."72 The fact that debt relief was popular among Virginians is also evidenced by the fact that Charles Smith boasted of his support for debt relief measures in a campaign speech to his constituents. 73 Virginians were no doubt also concerned about the harshness of their laws as compared to other states. The revisors of the 1873 Virginia Code remarked in abolishing imprisonment for debt, "the system... is regarded by so many as inconsistent with the liberal and enlightened spirit of the age." 74 Thus legislators were more inclined to extend relief, especially to innocent sufferers. Notably, most of the bills, including the married women's acts, were aimed at protecting families.

The married women's acts of 1875 and 1877 not only aided stricken households, but drew special attention to wives, 
hinting at another motivation among Virginia legislators in passing the statutes. As Richard Chused notes of the antebellum acts: 75

The country had seen bad economic times before... while married women's acts were a new legislative response. The fact that many of the acts had general statements adopting the notion of a separate estate for married women's property also suggests a broader purpose. The acts must therefore have been part of a larger evolution in the treatment of women by the law.

Both Chused and Basch note that the antebellum married women's statutes were accompanied by other legislation singling out married women for special treatment. Yet they disagree on the instigation for these measures. Chused claims that the development was a recognition by legislators "that women's role within the family had changed to encompass greater control over the raising of children and the disposition of family wealth."76 Basch on the other hand argues that the legislation was not connected with women's growing power within the domestic sphere. Rather, she argues that "the woman question was not a distinct catalyst for statutory reform until the $1840^{\prime} s, "$ when agitation by women and public attention created an atmosphere conducive to making statutory changes in the legal status of married women. 77

Until more is discovered about the married women's acts, it is difficult to determine how direct the influence of change in married women's legal status and social role was on the passage of the acts. In the state of Virginia, there is no record of organized feminist input in the passage of the 
Smith Act. No women's rights group existed in Virginia at this time: a fledging Richmond suffrage group established in 1870 under the leadership of John Underwood (former Chairman of the Virginia Reconstruction Convention -- an unpopular head of an unpopular cause) disbanded two years later. 78 General petition files are not available for this period, so there is no way to discover whether wives in Virginia, like women in New York, Massachusetts, Pennsylvania and Ohio, petitioned the legislature for passage of the statute. No public mention was made about women's support of the bill except for a remark by Smith that "a very large majority of the people, including the women, according to my observation, [are]... strongly in favor of this legislation."79 Thus Basch's contention about the relationship of feminist pressure and the passage of the New York married women's act does not seem to be borne out in Virginia.

While there was no organized feminist push for the married women's property bill in Virginia, and certainly no popular support of women's rights in the state at this time, there is reason to believe that some legislators were truly concerned about married women's rights. Charles Smith, like his counterpart Thomas Hertell of New York, was one such legislator. Hertell originally introduced the New York married women's legislation in a speech calling for justice for married women. Smith's speech is in fact remarkably similar to Hertell's, especially in its references to married women's "God-given rights." 80 Smith appealed to his fellow 
Senators: "Surely, then, the women of the state are entitled to such legislative consideration and protection in regard to their just and natural rights in property .... [T] have rights ... which men and legislators should feel bound to respect, is unquestionable." Echoing Hertell, Smith also compared the married woman's position under the common law to that of a slave, exploited and powerless: 81

... the legal disabilities of married women are peculiar to the common law. They originated in barbarous times, when the wife was a slave .... Hence we see woman in due course of time elevated from the humble position of the rude Sabine captive to the high and splendid place of the noble mother of the heroic Gracchi; to those grand, elevated, and true positions God intended her to occupy.

Smith championed the cause of women not only in sponsoring married women's legislation, but in pushing for the establishment of a female institution of higher education in Virginia. 82

How many men shared Smith's sentiments is of course impossible to determine. It is interesting to note, however, that a few other measures granting wives more freedom from common law restrictions were prosposed in the Virginia General Assembly during the 1870's. For example, the legislature enacted a statute in 1879 which for the first time granted wives custody of their children in certain circumstances, paticularly if the child was under seven or a female. 83 Although courts in many states had modified custody laws before the Civil War, Virginia courts had consistently followed the common law rule which gave the father custody of 
the children. 84 (Presumably this rule recognized that the husband was bound to support the children, or perhaps that children needed fatherly discipline more than motherly tenderness. ${ }^{85}$ ) The legislature also amended the provisions governing divorce in the Virginia code to provide divorce for women whose husbands had been fugitives from justice for more than two years. 86 Additional measures proposed during this period included another bill to allow married women to insure the lives of their spouses (which passed the senate), and a bill allowing the husband and wife to testify for and against each other in court. 87

Why some Virginia legislators favored the married women's acts and other measures, and why others were willing to overcome traditional prejudices in recognizing a more independent role for married women, is perhaps tied to a postwar change in attitude about the ideal of southern womanhood. The perennial debate about the Civil War as a watershed for Southern women continues to rage -- given the work of Suzanne Lebsock, Catherine Clinton, and Jonathan Weiner, it seems likely that there was not any great expansion of women's activities or roles as a result of the civil War. 88 Yet in light of the evidence in Virginia, there does seem to have been a recognition among men that times had changed and they could no longer support the myth of the submissive and dependent wife.

In his speech before the senate, Smith directly connected the need for a married women's bill with the transformation in 
women's roles occurring after the Civil War. He remarked: ${ }^{89}$

No one will contend that radical changes as to woman's position in the community have not been brought about within the last fifteen years, and particularly so in domestic matters. This bill is a partial remedy for such an upheaval of affairs and it will bring untold comfort and happiness to the women of Virginia and add so much, socially and materially, to the best interests of our people.

Two years later, Smith reiterated his recognition that changed conditions necessitated changes in laws regarding women. In presenting his resolution for a female institution of higher learning, he argued: "One reason urged in favor of those laws [the married women's acts] was the results of the war, and there is the same necessity demanding a similar act of justice to the daughters of the state contemplated in this resolution." 90 M.P. Burks, author of an 1894 treatise on married women's property law in Virginia, also noted a change stemming from the Civil War. He wrote that "[s]uch was the manliness and pride of our Virginia people before the late war that marriage settlements were not favored ... while now almost every volume of reports contains one or more cases touching the estates of married women." 91

Smith's reference in his speech to changes in "domestic matters" suggest that Virginia legislators were willing to admit the responsibilities a wife assumed within the home, but were reluctant to approve any actions which might encourage Virginia wives to be assertive in the public sphere. Even Smith, perhaps to garner more support for the bill, tempered his language regarding the bill's effects on women. He 
declared that he did not support women's suffrage, and armed his speech with many references to the bill's benefits for women: "Let us panoply women in the just measure of her property rights, that she may better enhance and embellish society, and purify our religion, and continue to elevate our people."92 He also countered arguments that the bill would inspire "freelovism" and turn married women into "irrepressible termagants." Thus the Virginia married women's act, in part supported for its easing of the harsh rules of coverture, represented a compromise between supporters of expanded rights for women and those who clung to ideals of the past. This compromise is reflected in the Smith Act's provisions, which left considerable control in the hands of the husband.

Suzanne Lebsock remarks in her article about the Reconstruction married women's acts: "Any significant change in the law of married-women's property ... amounted to a choice among evils, or among benefits, in the eyes of lawmakers. That being the case, it was no doubt possible for a small group of legislators with conviction to sway a much larger group of their ambivalent colleagues." 93 virginia legislators also had to pick among the benefits and evils of the married women's bill as smith presented it. In his speech, Smith claimed another favorable effect of the bill which undoutedly appealed to many Senators and House members: it would herald to the rest of the world that Virginia had entered a new, modern era. Thus he assigned the legislation a 
symbolic value as a sign of the commonwealth's acceptance of a "New South" ethos.

Historians of postbellum Virginia and the south have identified a significant movement launched by journalists, businessmen and other forward-looking men to convert the region to the doctrines of progress, especially in economic affairs. Calling their message the "New South Creed," Paul Gaston claims that these men embraced a program of industrialization and entrepreneurship so that the south might share in the nation's general postwar prosperity. At the same time the reformers wanted to eradicate the backward economic and social conditions which they suspected had caused the South's defeat. To accomplish these ends, the New South spokesmen attempted to "persuade the region to reconsider its ancient prejudices and redirect its energies into new paths." 94

There is considerable debate about how widespread and how complete Virginia's conversion was to the New South Creed. Jack Maddex in his book about the Virginia Conservative Party claims that most of Virginia's postwar political leaders, maturing in the Civil War era, embraced innovation. Like Gaston, Maddex believes that these men sought reasons for the Confederacy's defeat, and found it in the region's resistance to change and its economic backwardness. Maddex admits that some Conservative leaders still clung to the past and were suspicious of change, but argues that 95

... [t]he principal Conservative leaders ... consciously 
strove to adapt their part of the world to the tendencies of the bourgeois revolution of their time and to confer on it the benefits of industrial capitalism. Some opted for adaptation as a positive good; some, as a necessary evil; and some, as an irresistible necessity. However motivated, they co-operated to bring Virginia into the mainstream of Gilded Age America.

James Tice Moore is less sympathetic to the Conservative Party than Maddex, and contends that the political leaders' espousal of innovation was largely rhetoric. Most, he maintains, did not abandon their antebellum values. He writes of the Conservative leaders: "They welcomed economic growth, but only so long as it did not disrupt their elitist political, social and economic order in Virginia."96 Moore adds that the Conservatives' legislative record in the 1870's demonstrates that their rhetoric did not translate into practical, progressive measures.

Charles Smith fits into Maddex's mold rather than Moore's, suggesting that for at least some politicians in postwar Virginia espousal of a New South Creed was not merely rhetoric. Smith's life was shaped by his war experiences, and he felt himself part of a new generation: "I claim to belong to the new era in Virginia's history, resulting from the late war which brought about a new order of things changed so materially from the old regime of ante bellum times." 97 Smith's support of reforms such as debt relief legislation, and his creation of a senate committee to further agricultural, industrial and mining interests implies that he did not shy away from innovation. 98

Whether or not most other politicians during this period 
were merely mouthing New South slogans, it is apparent that they were concerned about Virginia's backwardness. Charles Smith recognized the political appeal of measures which symbolized change and therefore linked the married women's bill to Virginia's need to be up to date. In his speech before the senate about the bill, he chastised those senators with "biased and microsopic minds" who opposed the bill. He then explained that the married women's acts represented progress and enlightenment: 99

The disabilities of married women, the last remnant of ante-feudal barbarism, have almost entirely disappeared before the civilization of the age...[and are] old notions which in the necessities of modern life and a higher order of socialism and materialism have forced England and this country to get rid of and to clear out of the way of the grand progress of the age and the rapid strides of reformation.

Smith dismissed objections that married women's property reform originated in the North, "and that no good can come out of that modern Nazareth," by reminding senators that southern states had taken the lead in reform before the war. He proclaimed that if Senator John W. Daniel, the main opponent of the bill, were to go to other states in the South "he would be derided as a fossil and hooted as a bigot." Smith also preyed on Senators' fears that Virginia was losing out in the competition for prosperity by resisting innovations such as the married women's property act. "Why should Virginia continue to lag behind in blameful lethargy," he asked, "while the common struggle is going on among all the states for material wealth, social advancement, and greater fame?" He 
even argued that by not passing the married women's bill, legislators were preventing wealthy capitalists from locating in Virginia. These potential investors were afraid to bring their "fair daughters" to Virginia, as they were unprotected by law from fortune hunters. 100

Other than his remark about capitalists' daughters, Smith did not explain how the married women's bill would in any practical sense spell economic progress for Virginia. This omission suggests that the bill had principally a symbolic value: its passage would mean that virginia was no longer an anomaly among states. Unlike the married women's act in New York, the measure was not accompanied by a host of other acts undercutting the feudal vestiges of the common law, nor was there much favor in the state for law reform. Smith did mention that the statute would democratize the law regarding married women's estates by extending the benefits of equity to all wives in Virginia. He did not dwell on the point, however. Lebsock also notes that she-had seen no direct evidence in the south of a link between the married women's act and a democratic impulse. ${ }^{101}$ It was thus relatively easy for legislators to swallow a bill which would demonstrate their enlightened attitudes, but which did not go far in disrupting Virginia's social, economic, or legal structures. 
REACTION TO THE 1877 ACT

Historians have found that there was little public reaction when initial married women's bills were enacted in other states, and the same holds true in Virginia. Newspapers in the Commonwealth noted the Smith Act's passage, but few commented either favorably or adversely about it. The Richmond state, not mentioning the statute at all, remarked that the 1876-77 session of General Assembly had produced little legislation of importance. The Bichmond Dispatch merely printed the text of the law. Several regional newspapers, however, applauded the measure's effect of protecting the rights of married women. The Shenandoah Valley for example, presented the text of the act on the front page under the title "Married Women's Rights" and commented: "Among the many important acts passed by the General Assembly is the following, which is of general interest, and throws around the rights of married women protection for their property long needed." The Nerfolk Virginian was the only paper to express negative remarks about the bill, stating:

It will be productive of good in securing wives from the consequences of the improvidence of their husbands, but we fear it will also do harm in the impairment of domestic harmony, and the establishment of an independence on the part of wives that has always been especially distasteful to those notions of the marital relafions which have heretofore prevailed in this state.

When a married woman's property bill was proposed in the 
Virginia General Assembly in 1849, the Richmond Dispatch printed a scathing attack against the measure. It is therefore curious that there was no public debate about the 1877 Act. Perhaps Virginia newspaper editors believed that the subject was not newsworthy, given that debates had been waged about the measure for 30 years. Or perhaps Charles Smith's contention that the law would serve to protect women was sufficient to silence those people who feared that the law would disrupt marital bliss or create a race of Amazons. The Virginia legal community is the only group to have left a record of their reactions to the 1877 law. Lawyers were particulary vocal about the act, most likely because they were left to construe its provisions. The richest source of material about the Virginia bar's reactions to the act is the Virginia Law Journal, a compendium of cases and comments published in Virginia between 1877 and 1893. At least one article or editorial about the married women's property act or related issues appeared in every volume of the periodical.

Lawyers writing about the 1877 Act in the Virginia Law Journal divided into three camps -- those who vehemently opposed the measure and recommended repeal, those who endorsed the statute and called for further reform, and those of the majority group who reluctantly accepted the act but attempted to reconcile its provisions with traditional assumptions about the role of married women and the integrity of the common law. In linking the married women's act to changes in the status of women and innovation in the law, the lawyers' opinions provide 
further support for the argument that Virginia legislators saw the statute not merely as a debt relief measure, but as a measure which would alter the position of women in society and act as a symbol of the New south.

Very few attorneys spoke out publicly for repeal of the married women's act. The most strongly-worded opinion against the measure appeared in an 1880 Journal article by a lawyer named John Steger. Calling the provisions of the statute "radical in their character ... [and] dangerous in their tendency," steger first set out his legal objections to the law. He claimed that the act would promote fraud by its failure to provide for separate identification of the wife's property: an indebted husband would be able to protect himself from creditors by claiming that his property in fact belonged to his wife. As husband and wife were not allowed to testify for or against each other, the fraud could not be easily discovered. Steger also expressed fear that the Act would encourage endless litigation between husband and wife, and between the married couple and creditors, causing domestic and social strife. Finally, the author maintained that the legislation created uncertainty about the husband's title to his property, a hindrance to business transactions. 103

Steger continued his argument against the married women's act by outlining his much more serious moral objections to the legislation. He argued that the act destroyed the unity of marriage, with grave religious and social implications. The author decried the law's reckless subversion of the principles 
embodied in the Bible that man and wife are one, and that the husband is the head of the union. As society rests on this harmonious relationship, steger contended, the measure also threatened the stability of the social order by creating conflict within the marriage. Steger claimed that the married women's law was a result of the current tendency in Virginia "to take a materialistic view of all the relations of society, and a wide-spread disposition to regulate those relations as if they were wholly the offspring of society and subject to its laws alone." He concluded his article calling for the act's repeal. 104

A year after Steger's article appeared, one of the editors of the Virginia Law Journal felt compelled to defend Steger's arguments against an attack published in the nationally-circulated Albany Law Journal. The article had questioned Steger's use of Biblical authority, asking: "We believe Revelation nowhere says the husband shall absorb the wife's property .... if they be one, why give the male component any superior right of property?" The Virginia editor responded by quoting Saint Paul's teaching on male superiority, and by declaring his own opposition to "new-fangled" legislation such as the married women's act which was "all in conflict with the teachings of the common law, the 'blended wisdom of a thousand years.'" He ended his commentary by stating that he and his coeditor were "of the opinion that none of these 'reforms'(?) have been beneficial to society. " 105 
The most influential of the act's critics, however, was John Minor, professor of law at the University of Virginia from 1845 to 1895, who shaped the minds of several generations of Virginia lawyers. 106 (In fact, given Minor's influence, it is surprising that more lawyers in Virginia were not oppposed to the law.) The Virginia Law Journal quoted Minor as saying of the married women's act:

This legislation appears to the writer to be full of evil omen to the domestic peace and social order of the Commonwealth, and to the integrity of its people. The objections to the particular provisions of the act are many and great, but they are thrown quite into the shade by the threatening aspect of the policy upon which they are founded.

Minor stated that the act's policy proposed to subvert the principles of the common law, abolish the husband's position as head of the family, create conflict of interest between husband and wife, and encourage fraud and litigation.107 A student of Minor's remarked that the law professor condemned the married women's law "in words so caustic and sarcastic that they lingered on in [his] memory ... 40 years after they were uttered." 108

That men like John Minor and John Steger violently opposed a law adopted by all other states is perhaps not surprising given the traditional conservatism of the virginia bar. Yet the writings of Minor and steger also suggest that these men shared the deeply-felt desire of some southerners to preserve the institutions of the past in the face of change. Although there are many theories explaining these southerners' 
adherence to an antebellum ideal, perhaps two interrelated reasons for the postbellum conservative reaction can be viewed as fundamental. First, as Raymond Pulley suggests, the past represented stability and security to Virginians and other Southerners suffering from defeat in war and dislocation in Reconstruction society. In their idealization of antebellum values, many Southerners fought vigorously against changes such as industrialization and suffrage extension which subverted traditional principles of honor, deference and gentility. Their clinging to the past may in part be seen as a kind of defensive reaction, similar to the South's antebellum championing of slavery in response to abolitionist threats. On the opposite side of the same coin some Southerners also depised the new values threatening to replace the old -- materialism, egalitarianism, and a worship of progress. Not only were these values associated with the hated Yankees, but they also represented a particular threat to the traditional Virginia elite supported by an agrarian, hierarchical system in which social rather than economic position determined status. 109

The attack by attorneys against the married women's act was therefore phrased in terms of the need to preserve tradition -- specifically the integrity of the common law and the separate sphere of the Southern woman -- against the encroachments of new ideas. It is significant that these lawyers blamed the passage of the measure not on the women's rights movement, but on the growing materialism of the age. 
As one lawyer remarked, "We must not sacrifice marriage on the altar of mammon."1l0 Thus their predictions of the act's consequences were based on their more general fears about postbellum society rather than on a reasoned examination of the effects of similar laws in other jurisdictions.

One of the major reasons why lawyers opposed the act was that it contradicted the principles of common law. To these attorneys, raised on the teachings of John Minor, the common law represented a source of security as well as an established legal system. Minor himself was almost fanatical in his devotion to the common law. In an obituary for Minor, an attorney remarked: 111

[I]f the suggestion may be permitted .... his dislike of everything new in the law -- the pertinacity with which he clung to the ancient doctrines and procedures of the common law, and the strenuous opposition with which he met every suggestion of change, amendment, or amelioration, even though they were demanded by the changed conditions of society and approved by the inevitable growth and development of the law ... constituted a defect -- perhaps his only defect -- as a lawyer, an author, and a teacher.

Developments in late nineteenth century Virginia threatened the sanctity of the common law, and consequently represented a threat to lawyers devoted to the common law system. Statutory law such as the married women's act, which altered or abolished common law rules, was on the increase. And a few more progressive lawyers began lobbying for the adoption of a code of civil procedure to replace complicated common law forms of pleading. A group of Virginia attorneys, including many opponents of the married woman's law, fought against this 
reform, claiming that "all change is not reform, and all changes in established usages and forms are apt to bring about doubt, confusion and mischief."ll2 It is possible that these men opposed codification not only because of a stubborn loyalty to tradition, but also because the codes promised to democratize the law by making it more accessible to the lay person. In this way, codification challenged the lawyers' elite status. 113

Lawyers resisted changes in common law practices out of respect for "the wisdom of a thousand years," and also because they feared the results of untested legal principles. Yet the projected legal consequences of the married women's act -litigation and fraud - had little basis in reality. There was almost no litigation provoked between husband and wife, although the act did result in suits between spouses and creditors. But this litigation emerged as a result of the ambiguous wording of the statute, and not from contentiousness inspired by the law. While the law produced few incidences of fraud, political and economic dirty dealings were pervasive problems in postbellum Virginia and caused much concern among Virginians who saw the state's unwritten code of honor being violated. 114 (It is interesting to note that John steger was in charge of an investigation of a government scandal in the "Basement Offices" of the State Capitol during the 1870's.) Thus it seems likely that the lawyers who opposed the 1877 act projected their more universal concerns about the results of modern business and political practices onto this specific 
instrument of change.

To the members of the Virginia legal community who spoke against the married women's act, the measure posed a danger to another tradition already under attack -- the ideal of Southern womanhood. Men whose self-image was shattered both by the war and their inability to provide for their families, and who longed for the social stability of antebellum days, clung more tenaciously to the ideal of the Southern women. So the lawyers opposing the married women's act resented the further threat it posed to this ideal in allowing a wife to step out of her domestic sphere and be recognized as an individual under the law, again projecting the results of other postwar changes -- social instability, materialism -onto the statute. 115

Few voices spoke out against the married women's act; fewer voices strongly favored its provisions. Two brothers, Camm and Seargeant Patteson, were in the vanguard of the measure's supporters. Writing in 1886, Camm Patteson endorsed the act and recommended further reform. In an article suggesting changes to be incorporated in the upcoming revision of the Virginia Code, Patteson called for repeal of the provision of the married women's law which required a husband to join in his wife's conveyances and contracts. He argued in justifying this change: "[it] gives to the women of the land the rights to which they are entitled. It is due to them as a simple act of justice." In the same article Patteson recommended the repeal of other Virginia statutes which were 
blatantly unfair to wives. One such law took away a wife's dower rights if she committed adultery, but did not affect the husband's curtesy rights if he was guilty of the same offense. 116

Camm Patteson's brother Seargeant was the most vocal proponent of change in married women's laws. Seargeant enthusiastically welcomed the 1877 act, and like his brother, endorsed further reform in laws adversely affecting women. He based his support of the married women's law on two convictions -- that marriage was an equal partnership and that all outdated common law principles should be overturned by statute. In an 1887 article in the Journal, for example, Patteson wrote: "The Virginia married woman's acts [of 1875 and 1877] were but a step in the right direction. They only gave to women that which was theirs by the commonest rules of justice." Patteson claimed that reform of the feme covert status was merely a confirmation and extension of equity principles, which had first been introduced to avoid the "harsh and unjust dogmas" of common law. Asserting that progressive minds recognized the need for improvement in the property rights of married women, he chastised the General Assembly for its slow work: "The changes [for married women] that are real and practical are almost as imperceptible as the movements of the famous Muir Glacier of Alaska, which they say occupies at present nearly the same position it did two hundred thousand years ago. Our Legislature is moving at a somewhat similar rate of speed. "117 
Seargeant Patteson pushed particularly hard to abolish the "barbarous" common law rule that prevented husband and wife from testifying for or against each other. This rule was based on the legal fiction that a married couple acted as a single unit -- to testify against a spouse would amount to self-incrimination. And to testify for a spouse would create conflict of interest problems, undercutting the legal fiction of marital unity. While Patteson declared that "it is the plain duty of the Legislature to strike this one of the shackles of the common law out of existence," many other lawyers resisted change in the testimony rule on the grounds that it would encourage domestic strife. 118

Despite Patteson's support of women's rights, he declared that there must be limits to female emancipation. Patteson wrote of the legal reforms for women that "no law should be tolerated which, in the smallest degree, will deprive them of any of their gentleness." Where the demarcation line should be drawn is not clear from Patteson's writing. Like Charles Smith, he strongly objected to female suffrage, claiming in a vague way that giving women the vote would revolutionize their attitudes. Patteson thus contradicted his contention that marriage was in every respect an equal partnership by maintaining that the wife had no need of political representation. 119

Why would men like seargeant and Camm Patteson, who came from an old Virginia family and were raised in the traditions of the common law and southern womanhood, support the married 
women's act and push for further reform? Evidence reveals that the mother of these two men had a strong influence in their upbringing, and was in fact largely responsible for their education. 120 Thus the brothers may have developed a respect for women's capabilities and a realization of the need to give women more legal rights. But coupled with this solicitude for women was an even more urgent concern -- the need for Virginia to reform her laws to bring the Commonwealth in line with other, more progressive states. The arguments raised by the Pattesons in favor of the act and of other reforms echo the "New South" remarks made by Charles Smith in his 1877 speech before the Virginia senate.

Paul Gaston finds that the principal supporters of the "New South Creed" were born in the 1850's and reached maturity during Reconstruction. Their unique perspective, then, shaped their criticisms of the values of the antebellum south. 121 Seargent Patteson, the most outspoken critic of tradition writing in the Journal, was born in 1851. Although age is not a good general predictor of Virginia lawyers' attitudes, in this instance it is very possible that Patteson, like other New South spokesmen, was influenced by the consequences of defeat and humiliation. His arguments in favor of the married women's act certainly reflect a desire for progress as much as a concern for women's rights. Claiming that the common law evolved during the darkest ages of man's history, Patteson condemned Virginia's stubborn adherence to relics of barbarism, such as the legal fiction of marital unity, which 
kept the Commonwealth from advancing as quickly as other states. Patteson's recommendations of limits to women's reform may in part be a result of his emphasis of progress over female emancipation -- Virginia should catch up with other states, but had no need to be in the forefront in endorsing women's rights. Or it may well be that anti-feminist attitudes were more difficult to overcome than prejudices against "Yankee" values.

In their writings, the Pattesons continually linked law reform to progress. Camm Patteson remarked in 1886: "Beyond all question, the present condition of the law is a serious drawback to the prosperity of our people." 122 The two brothers worked incessantly to convince fellow members of the State Bar Association to adopt a code of civil procedure. In an 1889 speech before the Association, Camm remarked: ${ }^{123}$

Have you ever reflected, gentlemen, that owing to the improvements of our chemical and mechanical science, the growth of the railroad and telegraphic transportation, more than eight times the business is done now than was done thirty years ago? We live in a rapidly moving age, and the cumbrous forms of the common law are wholly unsuited to our institutions. They retard our development as a people...to keep abreast of the age we must catch the spirit of reform and act upon it.

Seargeant Patteson, in his capacity as a member of the Bar Association's Committee on Law Reform, also urged Virginia lawyers to consider merging law and equity systems in Virginia. His pleas fell on deaf ears. 124

In his examination of the attitudes of the promoters of progress in the South, Paul Gaston asserts that "it is not 
true... that the New South spokesmen were, or considered themselves to be, detractors of the old regime."125 Gaston's contention is not borne out in the case of Patteson, who did not restrain his attacks on common law practices and his criticims of lawyers who resisted change. Speaking of the conservative members of the Virginia bar fighting codification, Patteson remarked that these attorneys "would have been happy under Harold, or William the Conqueror, and pefectly blissful in the glacial epoch or the paleozic age."126 Patteson's irreverence may mark him as an aberration, but his words seem to suggest that not all spokesmen for the New South had an esteem for past traditions. Indeed, Jack Maddex notes that several Virginia newspapers "resented the facility with which young Conservatives brushed aside time-honored tradition in the name of progress." 127

The majority of lawyers writing about the married women's act did not vigorously support or violently oppose the measure. Instead, these attorneys occupied a position between the poles set up by steger and Patteson. Reluctantly accepting the measure as inevitable, this group of attorneys tried to justify the statute in terms of the protection of married women, and to interpret it so as to disturb as little as possible the tenets of common law.

The spirit with which most lawyers greeted the act was one of resignation. Many may have privately condemned the married women's law, but chose not to voice their opposition out of a lawyer's respect for statutory law and an 
acknowledgement of the inevitability of change. One writer in the Virginia Law Journal, for example, admitted in reviewing the progress of married women's acts that "this course of legislation at least evidences a widespread conviction of the utility and necessity of such statutes, and, to such concurrence of human thought any reflecting man must hesitate to oppose his individual views." He went on to caution against excessive tampering with common law doctrines, claiming that "upon the relation of husband and wife, as upon a cornerstone, rests the fabric of society." 128

Another contributor to the Journal, Henry Hudnall, expressed a similar reluctance to call for repeal of the act. Although agreeing with steger's moral objections to the statute, Hudnall suggested that his attitudes were outdated. He drew a parallel between his opinion about the act and that of Judge Waller staples discussing obsolete states' rights principles. As staples remarked: "These are, however, old-fasioned doctrines -- too old, perhaps, to survive the fancies of the present age." Hudnall concluded that "the legislative wisdom has made this act, for weal or woe, a part of the law of the land, and what we have to do is make it mean something."129 The legal community did attempt to make the act mean something, with intriguing results.

Those Virginia attorneys who expressed a resigned acceptance of the act did not maintain, as did the Pattesons, that the General Assembly enacted the measure in recognition of a married woman's right to own property. Rather, a lack of 
information regarding legislative intent allowed some members of the legal community to assign another meaning to the act -the defense of wives against improvident husbands. As one lawyer asserted in 1879: "So far as any intent is indicated in the act, it was the purpose of the Legislature to protect married women, as far as practicable, against the consequences of their husband's misfortunes, follies, or reckless disregard of their marital obligations." The writer carefully avoided inconsistency by claiming that married women's equitable estates had also evolved in order to the protect the wife. ${ }^{130}$ These lawyers thus did not admit the act's foundations to be egalitarian, or even economic (there is no mention of relief for debtors), but rather saw the intent of the act as chivalric.

At the same time the majority of contributors to the Journal proclaimed that the married women's act shielded women from wastrel husbands, these lawyers also approved of the measure's narrow provisions in terms that contradicted their construction of legal intent. They declared that the restrictions on a wife's capacity to contract and to sue were intended to safeguard her against her own lack of worldly knowledge. One lawyer explained:

The common law disabilities of the married women were largely for their own protection. If they should be wholly removed .... [the wife] would (all inexperienced and ignorant of business as our Virginia women are) be liable, either by the artifices of her husband, or of strangers, to fall an easy prey to those with whom she might come to have dealings .... she would be as a lamb amongst wolves. 
This author went on to contend that the act's provisions requiring the husband to join in his spouse's contracts and suits protected the wife against unscrupulous businessmen. It did not seem to to strike the writer that he had, in a previous paragraph, identified the husband as one of the predatory wolves. 131 Other lawyers as well were unaware of, or unwilling to admit, the inherent contradiction between their justification of the act and their interpretation of its provisions.

In accepting the statute, many attorneys clearly saw that the legislation represented a general tendency of states to abandon the principles of common law, a development which Virginians needed to follow to bring their state into "an innovating and aggressive age." But most Virginia lawyers were unwilling to completely refute the common law rules of coverture; therefore they adopted the 1877 act while construing its provisions as narrowly as possible. This tension between retrenchment and reform also found expression in the battle over codification. Members of the Virginia State Bar Association made countless speeches recognizing the need for change at the same time they were sending the detailed code proposals back to the Law Reform Committee for further consideration. 132

The majority of Virginia lawyers writing about the act, like the state's legislators, also realized that women's property laws should be changed to meet the demands of an era in which all other states recognized woman's right to own and 
control property. Nevertheless, the Virginia legal community found it difficult to reject the ideal of the Southern woman. The contradiction expressed in their rhetoric between the husband as protector and the husband as spendthrift reveals the tension experienced by these men between their perception of the need to recognize the married woman as an individual under the law and their desire to preserve the legal conditions which kept women in submission. 


\section{IITIGATION AND CONSTRUCTION, 1877-1887.}

In every American state, including Virginia, numerous court cases and further legislation followed the enactment of initial married women's statutes. Historians have struggled to fit the Chinese puzzle of piecemeal legislation and often contradictory cases into some kind of discernible pattern, with little success. 133 Analysis of Virginia supreme court of Appeals decisions concerning the Smith Act in the first decade after its passage also does not bring to light any single governing policy or framework. The inconsistent court rulings derived from a variety of factors. Judges frequently interpreted the acts according to different rules of statutory construction. Some argued that the measure was in derogation of the common law, and should therefore be construed strictly, while others argued that because it was remedial, the act should be interpreted liberally. The Virginia bench issued rulings according to individual public policy decisions as well. Many judges, for example, wished to prevent fraud and handed down narrow verdicts; others felt married women should have unrestricted enjoyment of their property and construed the statutes accordingly.

Virginia attorneys, writing in the pages of the Virginia Law Journal, strove to derive guiding legal principles from the poorly-drafted Smith Act and conflicting court cases. The lawyers' analyses reflect less a concern for the general policy implications of their interpretations than a desire to 
find rational doctrines to govern married women's law in Virginia. Nonetheless, construction of the 1877 act by the bar was no more consistent than construction by judges. It took legislative action, through approval of married women's property provisions in the 1887 Virginia Code revision, to clarify and simplify some of the more confusing aspects of married women's law in Virginia. 134

While many issues of construction arose in cases concerning the Smith Act, major controversy focused on four topics: the husband's curtesy rights; definition of the wife's estate, common law rules regarding spouses' testimony; and limitations on a wife's power to make contracts. Section 2 of the 1877 law declared that "nothing contained in this act shall be construed to deprive the husband of curtesy in his wife's real estate." This seemingly simple provision became a bone of contention in the courts and among private attorneys for the next decade. The first case in which the subject arose was Breeding $y$. Dayis, decided in 1883. In Breeding, a husband's creditor levied an attachment on the husband's curtesy interest in his wife's real estate. The lower court decreed a sale of the wife's property to satisfy the debt, holding that the husband had a present vested interest in his wife's land. In appealing the decision, husband and wife argued that under the terms of the 1877 act, the husband could claim no interest in the wife's separate estate during her lifetime. The creditor countered with the Smith Act provision 
protecting curtesy. Judge Benjamin Lacy declared that by the terms of the Act, the husband had no interest whatever in his wife's estate while she was alive. Lacy added that the law did not impair the husband's right to curtesy consummate after the wife's death, nor did it in any way affect Virginia laws of succession. Lacy therefore ruled that the 1877 married women's act destroyed the husband's tenancy by the curtesy initiate. He explained that curtesy was now "rather a shadowy estate. It is an interest which may possibly ripen into something tangible in the uncertain future." 135

In writing the Breeding opinion, Lacy found himself forced to reconcile two provisions of the 1877 statute which were in conflict -- the clause protecting a husband's curtesy and that declaring that the wife's separate estate could not be subject to her spouse's liabilities. Lacy chose to protect the wife's control of her property. He explained that he was carrying out the legislative purpose of the act: "The intention of the legislature is plainly to abrogate the common law rule to a great degree, that the husband and wife were one person, and give her the right to manage her separate property, and contract with reference to it."136 Lacy may also have wished to remove a potential impediment to alienation of the married women's estate in order to expedite transfer of property.

Whatever his motivations, Lacy's decision was not well received by many lawyers. The editor of the Virginia Law Journal, for example, stated: "The decision ... subverts 
another familiar and time-honored principle of the common law ... and leaves the doctrine of estates by the curtesy in a very anomalous condition." The editor continued by remarking that the act's protection of the husband's curtesy rights was nan attempt to give the wife all and reserve something for the husband; an absurdity which is made manifest by the decision in Breeding y. Dayis. "137

A subsequent case, Browne $y$. Bockover, dealt with the issue of the husband's right to curtesy consummate. Browne involved a struggle between the creditors of the husband's and wife's estate, where each claimed that his lien took precedence against the wife's estate. Judge Thomas Fauntleroy wrote that by the terms of the 1877 statute, curtesy consummate is defeated if a wife alienates her land during her lifetime, but not if she devises it. Thus the court held that the creditor's lien on the husband's curtesy interest took precedence over debts incurred by the wife. 138

Another set of uncertainties stemming from the Smith Act concerned what property was to be included as a wife's separate estate. The issue first arose in Williams $y_{2}$ Lord and Robinson, an 1881 case. In Williams, a merchant, Richmond Williams, became indebted to a number of merchants. He conveyed his stock of goods by a deed of trust for the benefit of the creditors who would accept the deed. Those creditors who accepted the deed sold their claims to williams' property to Williams' wife; she then opened a store in the same warehouse as her husband's trustee. The creditors who had not 
accepted the deed of trust filed suit against the Williams, finding Mrs. Williams' actions highly suspicious. Mrs. Williams argued that her purchase of the creditors' claims was a regular business transaction, open to every citizen in the Commonwealth. Judge E.C. Burks agreed, declaring that a wife's acquisition of choses in action constituted a "purchase" under the Smith Act and could be deemed her separate estate. Burks ruled that Mrs. Williams was a bona fide purchaser, thereby overlooking possibilities of fraud. But in ruling in the wife's favor, Burks limited his decision to the facts of the case. He wrote: 139

The act makes radical changes in the legal capacity and property-rights of married women in this state, and as it has been in operation for a few years only, and many important and probably perplexing questions are likely to arise under its provisions, we deem it judicious, on the present occasion, not to extend our construction beyond the precise requirements of the case as presented.

In a later case, $N$, and $W, R, R$, Co, $V$ e Prindle and Wife, Judge Lacy, also ruling on the issue of what constituted a separate estate under the Smith Act, was not as kind to the wife as Burks had been in Williams. In prindle, a wife had sued the Norfolk and Western Railroad Company for personal injuries incurred while a passenger on one of the company's trains. A lower court had denied Mrs. Prindle's claims to compensation for doctor's bills and for Mr. Prindle's loss of her services, ruling that these damages belonged to the husband and should be the subject of a separate suit in his own name. The lower court did, however, grant the wife $\$ 1,000$ 
in damages for personal injury. On appeal, Judge Lacy ruled that property could come to a wife only in the ways specified in the statute -- that is, "by gift, grant, purchase, inheritance, devise or bequest." He held that damages for personal injury did not fall under any of these categories, and that therefore compensation for a wife's personal injuries belonged to the husband. 140

Lacy approved of the married women's act, and expressed his favor in the prindle opinion: "To secure to the wife and the mother, in her own fortune, the means of rearing her children, is wise policy and a just and humane device of the law; and we are of the opinion to give to the legislative enactment in this regard its fullest legitimate scope." Lacy was not willing to go beyond the literal text of the married women's act, however, guiding his statutory interpretation by the principles of the common law. These principles, he declared, "are maxims of sound interpretation which have been accumulated by the experience and ratified by the approbation of the ages."14l It is curious that Lacy applied the common law strictly in Prindle but in Breeding $y$. Dayis swept away a good portion of the husband's common law rights of curtesy. This contradiction lends further credence to the idea that Lacy had been concerned in part with ease of property transfer in Breeding.

The issue of what property was included as a wife's separate estate assumed particular significance when a husband's creditors sought to subject his wife's estate to his 
debts. In Yates y. Law, Judge Lunsford Lewis laid down a strict rule regarding this situation. He declared that the law presumes that the husband is the owner of all the property which the wife possesses during coverture. The burden of proof fell on the wife to prove in litigation with her husbands' creditors that the property in question was her own, and that it was derived from a source other than her husband if he was insolvent. Lewis's ruling was based on a concern that the married women's act might leave "a wide door ... open to fraud. 142

Another provision of the 1877 Virginia married women's act which gave judges particular trouble was the requirement that a husband must be joined in his spouse's suits. In Hayes and Wife $y$. Mutual protection Association, a married woman sued to recover on a life insurance policy left to her by her father. Her husband joined in the suit, in conformity with the terms of the statute. The insurance company claimed that the lower court had erred in allowing the wife to testify. Under a common law rule unaffected by the Smith Act, spouses were not allowed to testify for or against each other; therefore, the company argued, the husband's interest in the wife's suit precluded her from testifying in her -- and consequently her husband's -- behalf. The supreme court of Appeals ruled that the husband had joined in the suit for conformity only. The wife's claim to the insurance policy was a chose in action which was her separate estate under the 1877 law, and thus her husband had no interest in the estate or the 
suit. By logical extension, the court held that the wife was also responsible for court costs. 143

Judge Francis Anderson, writing the opinion in Hayes, based his decision on a liberal interpretation of the 1877 married women's law. He stated: 144

The act was passed for the benefit of the wife, and it is not reasonable to suppose that the legislature, by requiring the husband to be joined with her as plaintiff, intended to deprive her of the important privilege of testifying in her own behalf -- a restriction which might defeat the settlement to her separate use, which it was the object of the act to secure.

It is possible that Anderson, like many of his contemporaries, disapproved of the common law rule regarding the married couple's inability to testify for each other, and seized the opportunity to undermine the rule.

The Virginia supreme Court relied on the Hayes decision in ruling in an 1888 case, Farley ve Tillare In Earley, a wife was sued in a matter relating to her keeping of a hotel. Despite the fact that the husband's lack of interest was less apparent than in Hayes -- he had previously been running the hotel -- Judge Lacy determined that he was joined in the suit as a nominal party only. Mrs. Farley was therefore allowed to testify in her own behalf. 145

Not all cases regarding married women's testimony were decided in the wife's favor. In Prindle, for example, Judge Lacy distinguished the two cases and held that the wife could not testify, as the damages she claimed were not part of her separate estate and her husband had a legitimate interest in 
the case. 146 In crabtree v. Dunn, Judge Robert Richardson ruled that where land is claimed by a wife as her separate property against her husband's creditors, she is not a competent witness. Judge Richardson was obviously influenced in decision by the fact that the wife in the case had attempted to perpetrate a fraud. 147

The "joining in" clause of the 1877 law regarding married women's suits led to other problems in court. In Alexander $y$. Alexander, a husband found himself a plaintiff in a suit with his wife in which he was also a defendant. Determining that the husband was joined with his wife as a nominal party only, Judge Drury Hinton ruled that wife was free to name her husband as a defendant. He wrote: "... when once this idea of legal unity has been so far severed that she may contract and be contracted with ... we can perceive no valid reason why she may not as well sue her husband as another at law." Hinton based his decision in large part on a determination that the married women's law was "obviously an enabling act." He argued that the statute should be construed fairly in order to carry out the intent of the legislature to give the married women full enjoyment of her separate property. He was also swayed by the fact that Mr. Alexander was thriftless and lived off his wife's money, while Mrs. Alexander was "an economical, energetic businesswoman." 148

The most controversial issue raised by the 1877 act concerned the wife's powers of contracting. Under the common law, a married woman's contracts were void because she could 
not bind her person or property. The Smith Act gave a married woman the right to contract "in relation to" her separate estate, with her husband joining in, and as a sole trader. The language of the statute raised many questions among lawyers. Could a wife contract for more than she held? Could she enter into a contract if she held no separate estate? What was the meaning of the phrase "in relation to?" Judge Lacy in crockett $\mathrm{r}$. Doriot settled one question by ruling that a wife could only bind the estate she possessed at the time of entering into a contract. In crockett, a wife had signed a note to start a business, which soon failed. She subsequently inherited a piece of land which her creditors sought to subject to her debts under the note. Lacy determined that the Smith Act did not give authority for married women to contract generally or to bind their person, and therefore they could not bind property acquired after entering into a contract. 149

In a later case, McDonald and wife $y$. Hurste Rurneld and Cen, Judge Thomas Fauntleroy also limited the wife's rights and liabilities in regard to contracts. In McDonald, a J.T. McDonald was carrying on a mercantile business in his name alone. He became indebted, and signed a note to satisfy his creditors. His wife also signed this note at her husband's request. A lower court held that Mrs. McDonald's separate estate was subject to satisfaction of this note because she had signed it. Fauntleroy ruled that because there was no evidence that the wife owned a separate estate when she signed the note, her property acquired after the obligation was made 
could not be liable for the debt. He stated that a wife must explicitly or impliedly charge her separate estate when entering into a contract. 150

Lacy and Fauntleroy did not elaborate on their reasons for limiting the wife's powers of contracting. Lacy merely stated that the act did not give authority for the married women to contract generally, and that the statute must be construed according to its explicit terms. Both crockett and McDonald had the effect of protecting the wife, both from her husband and her own mistakes. Possibly the two judges had this purpose of protection in mind when writing their opinions.

The Virginia married women's act was the subject of legal construction not only in the formal setting of the courtroom, but also among members of the Virginia bar. Lawyers were quick to analyze both the statute and the court cases, and especially to criticize the statute. Virginia attorneys complained continually about how difficult the language of the law was to understand. Walter Dabney called the act "obscure, ambigious, and difficult of interpretation." John Hunter added that the act was "not a marvel of legislation clearness," and R.G.H. Kean claimed that "it will be a lifetime before the courts will have done construing ... [t]he nearly inscrutable provisions of this statute." 151

The act's provision that a married woman could contract "in relation to" her separate estate gave rise to a host of 
questions from Virginia lawyers. Dabney, for example, admitted that he could not determine exactly what the phrase meant. He assumed, however, that if a married women owned a farm, she could contract to hire hands or purchase supplies, or rent it, but her contracts unrelated to the running of the farm would be void. 152 Kean, on the other hand, argued that an explict relation to the separate estate was not necessary for a wife to enter into a contract -- the legislature intended that she could use her estate as a basis of credit. Otherwise, Kean reasoned, the wife would find herself in an anomalous position where she could, if she owned land, make a contract for service to her farm, but not to buy food for her children. 153

Just as the 1877 statute's provision requiring a husband to join in his wife's suits had raised numerous questions, so did the parallel clause requiring a husband to join in his wife's contracts. The most perplexing and serious question for lawyers (and undoutedly for husbands in Virginia) was whether a husband was made fully liable for his wife's contracts by his joinder. Kean maintained that a husband was not merely a nominal party to the contract but acted as a co-contractor. He contended that if the legislature had intended otherwise, it would have specified so in the act. Therefore the husband was generally liable, but the wife could only be liable to the extent of her legal separate estate. Kean maintained that this provision was intended for the wife's protection. 154 
William Pettit responded to Kean's argument in an article entitled "The Virginia Married Women's Act -- Again." He asked why the General Assembly, which had already taken away most of the husband's rights to his wife's property, would impose an additional burden on the husband by making him fully liable for his wife contracts. He added that "the considerations and attachments incident to the relation of husband and wife should suffice to ensure the careful and honest cooperation of the husband in the matter." Pettit also cited Hayes and Farley and claimed that the reasoning of these cases led to the conclusion that if a husband is a nominal party to his wife's suits, he must also be a nominal party to her contracts. 155

Another hotly debated issue among Virginia lawyers was whether the married women's act authorized wives to become sole traders. Most lawyers concluded that the act contained no such authorization, and that a wife in Virginia needed her husband's permission to become a sole trader. Henry Hudnall wrote: "Should her husband refuse to let her become a sole trader, the act could not be pleaded in favor of her right to do so .... [H] is common law privilege over the person of his wife could give him the right to require her to close the business whenever he might see proper to exercise such right."156 John Steger agreed with Hudnall's statement, claiming that if the act did confer on the wife the right to act as a sole trader without her husband's permission, "it [would] authorize her to neglect her domestic duties whenever 
she may prefer the excitement of trade."157

The married women's act also called into question the applicability of an 1873 Code provision regarding intestate succession. Under the provision, a husband was entitled to all of his wife's personal estate, subject to her debts, if she died intestate (the wife was only entitled to half of her husband's personalty). By vesting personalty in the wife, the 1877 act made the future of this law of succession uncertain. A C.W.W. from Alexandria wrote in the Virginia Law Journal. that the act nullified the Code provision, because it was intended "to abridge and to some extent destroy the husband's rights." John Hunter countered with the argument that there should be no repeal by implication, and the act's silence about the provision was not intended to destroy this right of the husband's. 158

Lawyers writing in the Virginia Law Journal carefully set their interpretations of the 1877 statute apart from their reactions to the law. Walter Dabney, for example, stated in an 1879 article: "No attempt has here been made to expose any of the dangerous consequences which must ensue indirectly from the married women's law. Our effort has simply been, to arrive a the meaning of the act in some particulars as it now stands."159 And R.G.H. Rean wrote in $1886: 160$

I shall not enter upon the general question, whether this radical departure from the rules and principles of the common law was wise or the reverse of wise. It has been done, and will never be undone .... It is a move in the direction in of the principles and practice of the civil law, towards which, as a more scientific system, and one better adapted to the exigencies of a highly organized 
state of society, the whole English-speaking world appears to have a decided drift. My object is to examine this act, with the view of determining, as far as I can ... what the purpose, meaning, and effect of its provisions are.

The search by Virginia lawyers for coherent principles to guide construction of the 1877 married women's law reflects a widespread tendency in the late nineteenth-century American legal community, particularly among academicians, to attempt to systematize the law. G.E. White, in his historical study of tort law in America, notes this emphasis on principle over policy. He explains: "[T]he late nineteenth-century academic-judicial symbiosis placed a high value on the achievement of order and coherence in the fields of law. A successful law review article or treatise was one that 'illuminated' a field by propounding doctrines capable of continuing to organize an increasing number of cases in an intelligible fasion." 161

Emphasis on rationalizing the law no doubt had an influence on the Virginia Code revisors in their preparation of the married women's property provisions of the 1887 Code. Those provisions were an effort to address the many inconsistencies revealed in the 1877 law and the court rulings handed down during the 1880's. Unfortunately, the Code sections led to more controversy, and in 1900 the legislature once again stepped in to clarify the law governing married women's property in Virginia. 
THE_CODE_REVISION, THE_1890'S_AND THE_ACT OE_1200.

The 1887 Virginia Code eliminated many of the provisions of the 1877 Smith Act -- such as the "joining in" clauses -which had led to litigation in the decade after the law's passage. But by retaining some common law limits on the wife's control of her separate estate, the Code produced new controversies and more litigation. During the 1890's, as in the 1880 's, lawyers attempted to explicate the law regarding married women's property. Finally, a comprehensive act passed in 1900 eliminated most of the restrictions of coverture. Background material about the 1900 statute is even more scarce than evidence about the 1877 law. It is likely, however, that the legislation was again enacted because of a convergence of influences -- specifically, a concern for clarification of married women's property provisions, and a desire to give wives in Virginia greater control of their separate property. As historians have found of other states, no generalization can be made about Virginia legislators' attitudes toward married women in the late nineteenth century. 162 But the net result of the General Assembly's actions from 1877 to 1900 was a significant step forward for married women in the state. In 1884, the Virginia legislature authorized the appointment of waller Staples, E.C. Burks, and John Reily to update the state's 1873 Code. ${ }^{163}$ All three of the code revisors were lawyers, and Burks and Staples had served on the Supreme Court of Appeals from 1870 to 1882. The revisors were 
therefore cognizant of the imperfections of the 1877 act and the controversies which had ensued after its passage. The text of Chapter 103 of the Code, which contains the married women's property provisions, clearly reflects the revisors' awareness and acknowledgement of the problems stemming from the Smith Act. Burks in fact later noted: "There is not, perhaps in the whole code, any chapter of more importance than that relating to the property rights of married women, and no subject within the scope of their work to which the Revisors gave more anxious consideration, or upon which they bestowed more care."164 Working within the limits set by the General Assembly not to make any radical departures from existing law, the Code revisors were able to make beneficial changes in the law governing married women's property rights. These changes not only had the effect of clarifying the law, but also resulted in increased freedom of action for married women. The Code revisors had anticipated the issue arising in prindle regarding the extent of a wife's separate estate, and addressed the problem in section 2284 of the Code. The language of the Smith Act was amended so that a married woman's estate would include any property she subsequently acquired "by gift, grant, purchase, descent, devise, bequest, or in any manner whatever [italics mine]." To avoid any future controversy, the revisors specified as well that "rights in action, damages for a wrong, and compensation for property taken for public use," belonged to the wife. The only limitation to the wife's acquisition of property was that 
she had no right of action against her husband for an injury to her person or reputation committed by him before or after marriage. 165

The new Code also stipulated in section 2287 that all proceeds from work performed by a married woman for anyone but her husband and children was to be her separate estate. 166 Thus a wife could not be remunerated for housework (this vestige of coverture has remarkable staying power), but she did gain control of her wages. Surprisingly, the provision concerning wages sparked no controversy among the public at large or the legal community. Most likely there were too few white working wives in Virginia for it to have much impact, and middle to upper class attorneys were hardly affected by the change. 167 The Code provision was not a very powerful weapon for the wife whose husband still insisted on taking her wages.

Section 2287 of the Code also quelled debate about whether a woman needed a husband's permission to act as a sole trader. It specifically authorized her to engage in trade or business as a feme sole. The only restriction under this provision was that she could not be a business partner with her husband. Presumably, this restriction was retained to prevent fraudulent trading practices. 168

The code revisors made a valiant attempt to clarify the provisions of the 1877 act regarding a wife's contracts. Section 2288 dropped the phrase "in relation to" and specified that a married woman could make contracts "in respect to such 
trade, business, labor, service, and her said separate estate, or upon the faith and credit thereof." Despite this amendment, controversy was to continue about the scope of the married woman's contracting power. Code section 2288 also made a crucial change in married women's property law by stipulating that a wife could enter into contracts and sue or be sued on any matter relating to her separate estate as if unmarried. Section 2297 supplemented this clause by specifying that it was no longer necessary for the husband to join in any future contracts made by his wife, or in any suits by or against her, relating to her separate estate. Thus the Code eradicated the problems raised in Hayes and other cases about a married couple's testimony, and ended questions concerning a husband's liability for his wife's suits and contracts. Section 2295 further clarified the law governing the wife's contracts by stating that all of her future contracts would be considered made in reference to her estate, both statutory and equitable. 169

Section 2293 of the 1887 Code resolved the issue worrying lawyers concerning the law of intestate succession. That section provided that the husband would inherit all of his wife's personal estate, subject to any debts, if she died intestate. The code also continued to preserve the husband's curtesy rights, and stipulated that the wife could not deprive her husband of curtesy by her sole act. The revisors took into account the ruling in Breeding $v$. Davis, however, by specifying that preservation of the huband's curtesy rights 
did not entitle him to possession or use of his wife's separate estate during coverture. Section 2296 of the Code barred a husband from curtesy if he deserted his wife and the desertion lasted until her death. 170

The 1887 Code protected equitable separate estates by declaring in section 2294 that "[s]uch estates shall not be deemed to be within the operation of the said sections, but they shall be held according to the provisions of the respective settlements thereof." And the revisors did not make any of the Code provisions retroactive: Section 2297 stated that all rights and limitations established or accruing before the code went into effect would be unimpaired. The revisors were obviously guarding against constitutional challenges in protecting vested rights, but this section created a good deal of confusion by establishing yet another kind of separate estate. By 1888 married women in Virginia could own property governed by common law rules, equitable rules, the Smith Act, or the 1887 Code. 171

The Code did preserve some features of coverture. Husband and wife were still not allowed to be witnesses for or against the other: the revisors had inserted a clause in a draft of the Code to abolish the common law practice, but the legislature struck it out. 172 The husband was still responsible for his wife's torts not connected with her separate estate. M.P. Burks, a lawyer who published an 1894 treatise on married women's property law, wrote that this provision "was no oversight, but was intentional from reasons 
of public policy. He [the husband] is still her protector and defender -- she is still under his cover, wing, or protection -- bound to obey him, and presumed to act under his coercion so far as affects her personal torts."173 Thus old attitudes persisted along with change.

In drafting Chapter 103 of the new Code, the revisors probably had clarification and rationalization of the law foremost in their minds.174 The Chapter's sections specifically addressed issues raised in the decisional law and in commentary by attorneys, and were undoubtedly intended to prevent further litigation and controversy. As E.C. Burks later noted: "The qualifications and exceptions are very few, and the fewer, I think, the better; for it is these that mar the symmetry of the law and produce much of the difficulty in its administration." 175 The revisors may also have wished to remove shadows of doubt from married women's business transactions. Lawyers in the Virginia Law Journal had expressed concern that because of unsettled issues stemming from the Smith Act, merchants and businessmen in Virginia could not accept a wife's notes with complete confidence.176 By providing that a married women could contract on the faith and credit of her estate as a feme sole, the revisors helped to resolve uncertainties.

It is also likely that the expansion of married women's legal rights brought about through the Code was not merely a byproduct of amendment. E.C. Burks, believed to be the principal author of Chapter 103, openly confessed his dislike 
of the harsh rules of coverture in an 1891 address before the Viginia State Bar Assocation. He recounted the disabilities of the wife under the common law, and stated that coverture put married women in a "pitiably helpless condition." Relief through equity was, Burks claimed, "an undeniable judicial confession that the rules and principles of the common law, in respect to the property rights of married women, were, to a large extent, unjust and unwise." He wholeheartedly approved of the married women's acts.177 It therefore seems probable that Burks fully intended to extend the wife's control of her estate to the limits set by the General Assembly.

In spite of the 1887 Code amendments, debate about married women's property law did not cease when the code went into effect on May 1, 1888. Controversies continued to arise, and lawyers continued to volley issues back and forth in the pages of Virginia's legal periodicals. The Virginia Law Journal ceased publication in 1893, but construction of married women's law continued in a new journal, The Virginia Law Register, which first appeared in 1895. Lawyers also discussed the subject at the annual Virginia state Bar Association meetings, and their remarks are recorded in the Association's annual minutes. The topic created so much confusion that several attorneys prepared extensive treatises on the subject. M.P. Burks, reporter for the supreme court of Appeals and the son of E.C. Burks, wrote a 90 page monograph on married women's property law in Virginia, published in 
1894. Burks remarked in his study: "So much of the property in this state is held by married women, and so much of the business is conducted in their names, that it has come to be a necessity that every lawyer should have some acquaintance with the remedies of creditors, and with the powers and responsibilities of married women holding separate estates."178 Many questions regarding married women's property law were finally put to rest by the 1900 act, which repealed most of the Code provisions, and again extended the legal rights of married women.

Although the Code of 1887 eliminated the 1877 act's requirement that the husband join with his wife in her suits and contracts, problems stemming from the requirement did not immediately disappear. In Norfolk and Western R.R. Co. $V$. Dougherty and Wife, decided in 1895, Judge George Harrison ruled that it was in error for the husband in the case to join his wife in a suit. He therefore reversed a decision granting the wife an award for injury. Harrison declared that as the wife's legal interest alone was affected in a suit for damages for an injury, the wife must sue alone under code section 2288. This strict ruling was based in large part on the fact that the case would have been dismissed if it had been tried on the facts. 179

In a case decided soon afterwards, Richmond Railway and Electric co. ve Bowles, a slightly different issue arose regarding a wife's suits. In Bowles, a woman sued for injuries by her next friend, and the appellants charged that 
this procedure was in error. The court disagreed, stating: "Her next friend was but a shadow, and yet we are asked to declare that the intervention of that shadow shall defeat the rights of the substantial party in this suit." 180 The editor of the Virginia Law Register, E.C. Burks, agreed with the Bowles ruling, remarking that "it would shock the sense of justice to hold that for this reason only the plaintiff should fail in her action."181 Thus bench and bar acknowledged a married women's right and ability to bring suits in her own name.

One debate which evolved from the code was how an equitable estate was to be distinguished from a statutory estate. Section 2284 of the code protected the creation and operation of equitable estates, but did not provide any guidelines for determining when a separate estate is established. The issue was important becuase of the different rights and liabilities attaching to the two different estates. The problem first arose in Dezendorf $\mathrm{V}$. Humphreys, decided in 1898. In Dezendorf, a married woman was willed a piece of property with the express provision that she could not convey or encumber it. Judge James Keith determined that because the will imposed restrictions not in the code, but which were consistent with the rules and principles of equity, the estate was clearly an equitable one.182

An issue supposedly settled by the Code was what property was to be considered the wife's separate estate. The subject arose in Bowles, where the wife claimed loss of time and cost 
of cure as an element of damages in a tort action against a trolley company. The court ruled that despite the code provisions, a husband was still entitled to the wife's services, as the common law rights, duties and obligations of the husband and wife remained unchanged under Virginia law, unless specifically altered by statute. Therefore, damages for a wife's loss of time belonged to the husband, unless the wife was a sole trader. And the cost of the cure was also an element of the husband's damages, unless the wife could claim that she paid out of her separate estate. 183

E.C. Burks in the Virginia Law Register called Bowles an important case. Burks suggested, however, that the husband was entitled to the services of the wife only in a qualified sense. He argued that under section 2287 of the Code, the wife was not entitled to compensation if she rendered service to her husband. But, he added, "she is under no legal obligation to serve him, whatever her moral duty may be. The statute, to that extent, emancipates her. Her husband cannot coerce her to labor for him, and she is given the unqualified right to labor for herself." 184

The issue which continued to provoke the most comment from lawyers was the extent of the wife's rights to make contracts. The code raised new questions -- did a wife now need to own a separate estate to make a contract, and if so, was she liable only to the extent of her present estate under the Code? The Virginia Law Register in particular devoted considerable attention to the subject. William Minor Lile, 
successor to E.C. Burks as editor of the Register, in fact poked fun at himself, saying, "If any of our readers are disposed to believe that this subject is an editorial hobby, attention is called to the fact that at least three numbers of the current volume have contained no reference to it." 185 The question was undoubtedly important because of its commercial impact -- a woman's contracts could not be accepted with complete confidence until the court resolved the issue. The question did not come before the supreme Court of Appeals until 1900, however. During the 1890's, it remained an unresolved and much contested issue.

In his 1894 treatise, M.P. Burks instigated the controversy regarding married women's contracts. Burks claimed that under the Code a married woman who possessed no separate estate could not make valid contracts. 186 The next year, E.C. Burks added to the debate. Burks questioned

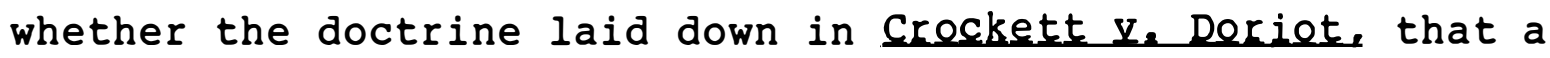
married woman could not contract in reference to an estate acquired after the contract was made, applied to estates under the code. He did not hazard a guess. 187

In 1898, William Lile elaborated on the issue in an article entitled "General Contractual Powers of Married Women under the Virginia Code of 1887." Lile remarked that the Code was clearly drafted except in its definition of the general contractual powers of the wife. Nowhere in the Code, he claimed, was there language requiring property qualifications in order for a married woman to contract, and he argued 
further that neither the language nor general policy of the statute would warrant such a qualification. Lile contended that under the Code, a wife who owned a separate estate could contract in anticipation of a future estate. Therefore, a married women who did not possess property should also be able to contract in relation to such future estate.

Lile also pointed out the inconsistencies which would result if M.P. Burks' interpretation was followed: a wife with a statutory estate worth one cent could bind herself personally to an unlimited extent while a wife without one cent's worth of estate could not contract generally, "even to the buying of a breakfast!" And further, he argued, any property owned by a married women and acquired since May 1 , 1888 could be considered some estate -- "the dress in which she is married -- the cracked mirror before which she adorns herself, and the pieces of brass jewelry which furnish the adornment." Lile concluded that the Code revisors could not have drafted the code to produce such absurd results, and therefore intended that a married women need not own a separate estate in order to contract. This intention, he contended, was based on the revisors' purpose "to completely. emancipate the wife for the future so far as her right to make contracts is concerned." 188

In a note appearing shortly after Lile's article, M. P. Burks defended his stand against Lile's attack. Chapter 103 of the Code must be taken as a whole, Burks claimed, and not read in separate parts. And although one must look to the 
statute first in construction, Burks maintained that it was admissible to look to surrounding circumstances in construing the Code. Burks argued first that the Code revisors were limited by the legislature's provision that they not to make any radical changes in the present system of laws. To have extended contractual powers to married women who did not own separate property would have been too radical a departure from the Smith Act. Burks also contended that the language of the Code itself indicated that married women needed some kind of property in order to contract. He reasoned: "If the object and purpose of the Revisors had been to emancipate all married women from the disabilities of coverture, there would have been no need for Chapter 103 ... but it might have been accomplished in a few brief sentences in one section."

Burks confessed that he could not answer Lile as to what amount of separate estate a wife needed in order to contract. He stated that what was classified as paraphernalia under the common law ("cracked mirrors, homespun ginghams") would not be considered a separate estate. Common sense dictated that a creditor would not accept the note of a woman who did not have an estate of value. Burks argued that the issue could be determined on the evidence of each particular case without any difficulty. 189

Seeking support for his side of the argument, Lile called for a public discussion of the subject. Lile posed the question: "Must a married woman, who is not engaged in trade or business, possess separate estate, acquired as contemplated 
by Chapter 103 of the Virginia Code, in order to make a valid endorsement of her husband's note, for his accommodation?" The Register received ten replies to the question, seven agreeing that no separate estate was necessary in order for a married women to contract. One lawyer wrote that a case had already been decided in Richmond on the basis of this opinion. 190

In a paper read before the Virginia state Bar Association, William Pettit proposed that the controversy should be terminated by amending the code. He argued that the wife "should be put fully and completely in the position and condition of any other person legally competent to will, act and transact business." Pettit also recommended that other common law impediments be abolished. He contended that it was foolish for the husband to be responsible for his wife's torts: the modern wife would resent M.P. Burks's statement that "she is bound to obey her husband ... and is presumed to act under his coercion."19l Another lawyer, maintaining with Pettit that the Code provisions regarding maried women's contracts were hopelessly tangled, suggested that each wife in Virginia receive a five dollar "emancipation piece" upon her marriage and be free to contract to her heart's content. 192

In 1900, the Virginia supreme Court of Appeals finally ruled on the question of whether a married woman needed a separate estate in order to contract in Hirth $\mathrm{x}$. Hirth. The court ruled that under section 2288 of the code, only married women who owned property were free to make contracts. 193 
William Lile, in a short comment on Hirth, wrote that "the decision in the principal case has been awaited with interest by the profession .... We had thought the question a difficult one, until the court elucidated it in a single sentence." Lile added: "One question yet remains, which the court will doubtless find equally simple -- and that is, How much separate property must the wife possess in order to qualify her to make contracts?n194

The ruling in Hirth $v$. Hirth was not to remain in effect very long. A month after the case was decided, the Virginia General Assembly enacted a law which repealed most of Chapter 103 of the Code. The 1900 act stipulated that

a married woman shall have the right to acquire, hold, use, control, and dispose of property, as if she were unmarried, and such power of use, control, and disposition shall apply to all property of a married woman heretofore or hereafter acquired .... A married woman may contract and be contracted with, sue and be sued, in the same manner and with the same consequences as if she were unmarried, whether the right or liability asserted by or against her shall have accrued before or after the passage of this act.

The law, being retroactive, swept away the estates governed by Smith Act and Code rules. The act further provided that a husband would no longer be responsible for his wife's torts. The only restriction on the wife's right to her estate was that she could not deprive her husband of curtesy by her sole act. The 1900 measure also protected equitable estates, kept intact the law regarding intestate succession, and limited the minor wife's power over her separate estate. 195

There was almost no public reaction to the 1900 act; 
therefore, reason for its passage are difficult to discern. (Perhaps the technicalities of the previous acts had completely exiled discussion of married women's law to the legal forum.) The act encountered little opposition in the legislature as well. It may have represented a compromise: legislators were aware of the impediments of the old married women's measures and were willing to grant Virginia wives almost complete freedom from coverture in order to streamline the law. But hidden beneath the compromise was a recognition by the Virginia General Assembly that the married woman was capable of standing on her own in the public sphere. 


\section{A SERARATE IDENTITY}

All of the recent studies of married women's property laws have concluded that the acts were not revolutionary in purpose or effect. Basch, for example, finds that "the evolution of the legal status of New York wives in the nineteenth century was marked more by continuities than by changes."196 Basch goes on to hypothesize that future studies of acts in other states will reveal the same continuities. At first glance, the Virginia married woman's experience seems similar to that of her counterparts in New York. Initial legislation was limited, amendment came slowly, and the Virginia supreme Court of Appeals often undercut the potential impact of the General Assembly's actions. Yet the changes wrought by the married women's acts in Virginia -- and in other states -- must not be minimized or overlooked. Basch began her study with the expectation that the married women's legislation heralded a watershed for women in the nineteenth century, and thus her discovery of recalcitrance and resistance led her to view the acts in New York as limited. But beginning with no expectations, one can emerge with a different view of the married women's acts. preliminary evidence about Virginia suggests that the statutes themselves led to some real changes in the lives of the state's married women, and that the acts had a "ripple effect," leading to other legislation which recognized the separate legal identity of the Virginia wife. 
The most obvious benefit which the 1877 act and subsequent legislation bestowed on married women was increasing control over their own property. From having no power over their estates except what equity provided before 1877, Virginia wives by 1900 had gained the right to make contracts, sue in their own names, devise property, and in general to make independent decisions about their separate estates. The 1877 act had regulated the wife through a "special treatment" norm -- keeping her under the protective wing of her husband. 197 But the act of 1900 largely freed the married women from the protection and restrictions of coverture, and treated her as an equal to her husband. Thus in twenty-three short years, married women in Virginia gained substantial legal rights.

Although a direct connection is not always evident, it seems very likely that passage of the 1877 Smith Act prompted other legislation recognizing the married women as a distinct legal entity. The measure which had the most impact in reforming the common law (and which met with the most resistance) was an 1894 act allowing a married couple to testify for and against each other in civil cases. The act also provided that spouses could testify for each other in criminal cases, but could not be forced to testify against each other. 198 Many lawyers in Virginia had been pushing for a change in the law regarding testimony, particularly because of married women's legislation. One judge declared that the restriction on the husband acting as a witness hurt married 
women in suits against creditors. 199 E.C. Burks, in his 1891 address before the Bar Association, declared that the 1877 act and the 1887 Code provisions made a testimony law "indispensable to the due administration of justice, having regard not only to the interests of the husband and wife but of creditors and purchasers and the public as well."200 The resistance of the General Assembly was probably due in part to fear of encouraging fraud, but also in large part to a fear of subverting the legal fiction of marital unity. The passage of the 1894 Act therefore signified that Virginia legislators were willing to topple yet another prop holding up the rules of coverture.

The legislature passed other acts during the last quarter of the nineteenth century acknowledging married woman's separate identity under the law. As noted previously, an 1879 statute gave wives the right to custody of their children in certain circumstances. Virginia courts continued to recognize this right. In Owens $\mathrm{k}_{\text {, }}$ Qwens, a 1898 case, the court stated: "A woman compelled by her husband to resort to a divorce ought not to obtain it at the expense of losing the society of her children."201 The General Assembly passed an act in the 1891-92 session which allowed a female personal representative to continue in her position after marriage, another acknowledgement that a woman did not cease to be a responsible adult when she became a wife.202 In 1892, the legislature bestowed on the minor married woman, who had not previously enjoyed the same benefits as the adult wife, the right to sell 
her real estate by filing a bill of equity through her next friend. This bill was to state "all the facts calculated to show the propriety of the sale."203 Although the act was still protective in nature, it represented a tip in the scales away from protection toward greater freedom for the married woman.

In 1896 the General Assembly passed a bill which stated that every contract of a married woman made would be deemed made in reference to her legal and her equitable estate, including the corpus of her equitable estate if the estate's rents and profits were not sufficient to satisfy a judgment. 204 This act was largely a technical change in equity rules, designed most likely to protect creditors. But it served as a sign that the legislature was ceasing to protect the married woman from her own actions. In the session of 1897-8, the General Assembly enacted legislation allowing a married woman to sue in her own name in all cases where she had been previously required to sue by her next friend. 205 In May of 1900, the Virginia Law Register summed up the reforms in married women's law passed in the year's session of the General Assembly: 206

She has been eliminated altogether from section 2513 of the Code, which prohibited her from making a will; from section 2615, which classed her with infants and lunatics, in making leases of lands; and from section 3435. where she was similarly classed, in respect to the time limit for a bill of review. And, finally, every line of chapter 103, containing any allusion, express or implied, to "separate estate," or intimating in the remotest way that a married woman holds her property in any manner different from that in which the husbands holds his, has been eliminated. 
With the exception of the married women's property acts and the law relating to testifying, most of the acts passed in the late nineteenth century regarding married women's legal rights had a relatively minor impact. Yet they are all significant in that they helped to further erode the concepts supporting coverture. As in the case of the married women's property acts, the legislators passing these bills probably held the goals of rationalizing the law and easing business transactions above feminist purposes. Again, however, these laws could not have been passed unless legislators' attitudes had changed about the rights and capabilities of married women. And the measures were not merely a recognition of women's enlarged role in the domestic sphere. The law regarding spouses' testimony, for example, assumed that the wife would be making contracts and appearing in court. Even a minor married woman was recognized to have the ability to sell her real estate.

Legislators in Virginia were changing their opinions about the proper role role for the married woman; there is evidence that the state's lawyers were as well. After 1890 , vehement reactions to reform in the laws for married women such as those of John Steger could no longer be found in the pages of Virginia law journals or the in the annual minutes of the State Bar Assocation. Perhaps this silence resulted in part from a change in editorial policy in the Virginia Law Journal and the Virginia Law Register. More likely, it sprung 
from a gradual, if sometimes grudging, acceptance of a new legal status for the married woman. Thus in the 1880's and 1890's, married women's property law became a subject for construction rather than criticism among Virginia attorneys. Lawyers greeted the 1900 Act with approval, not only because it clarified the law, but because it recognized the capabilities of married women. As the editor of the Register. wrote: 207

[T] he legislature has attempted to completely remove the married woman from her ancient companionship with infants and idiots, and to place her, clothed and in her right mind, on the same plane with her husband, in respect to property and personal rights, powers and liabilities .... That sacred idol, known as the wife's "common law estate" - land acquired by a wife prior to 1877 -- has been dethroned and flung into the mass of common things, and is no more a thing to be worshipped. It is no longer holy ground; and the wife may walk upon it with her shoes on ... may sell it for filthy lucre. Nor may his craven lordship, the husband, say ever a word.

The opinions of Virginia supreme Court justices also reveal an increasing acceptance of married women in the public sphere. In an article about antebellum Southern women and divorce, Jane Turner Censer writes that courts "applauded feminine capability in domestic matters, but ... frowned upon assertive behavior." 208 It is doubtful that prewar Virginia judges accepted businesswomen with equanimity. In the state Supreme Court decisions of the 1880's dealing with married women's law, a few judges expressed the view that married women needed to be protected, but none spoke negatively of a wife engaging in business. By the 1890's, even the rhetoric about protection died out and the judges treated businesswomen 
as accepted members of society. There is no evidence that justices viewed wives pressing their claims in court as aberrations. As there was little general public reaction to any of the later legislation regarding married women's rights, it is impossible to determine whether legislators' and lawyers' opinions were echoed by the rest of the Virginia population. The lack of comment suggests, however, that there was no violent opposition.

There is, in legislation and in lawyers' attitudes, evidence that the legal fiction of marital unity, which had supported the common law disabilities of married women, was gradually eroding in late nineteenth-century Virginia. Despite some restrictive rulings by the supreme Court, the continuities that Basch found in New York are not as apparent in Virginia. But legislative enactments and private attorneys' opinions are only a fraction of the evidence needed to determine how the legal reforms translated into real changes for married women. An extensive study of deeds and wills, similar to that performed by suzanne Lebsock for antebellum Petersburg, is necessary to ascertain what and how much property married women owned, how they disposed of it, and what control they actually exercised over their separate estates. In addition, a review of private correspondence is needed to uncover Virginia wives' private thoughts about the married women's property acts and related legislation -whether they favored the measures, and especially whether public laws could be enforced in the private sphere against a 
husband's wishes.

Despite the lack of available research about Virginia wives in the postwar era, one piece of evidence indicates that some married women were both aware of the changes in their legal rights and were taking advantage of those changes. A sizeable number of married women were exercising their rights under the law. In most Court of Appeals cases, the wife was not a passive victim of a husband's attempt to avoid creditors, but was an active participant in the economic system. It is probable that married women acting as businesswomen appeared even more frequently at the lower court level.

The married women's acts in Virginia may have benefitted only those wives who owned a fair amount of property, however. The 1877 act was undoubtedly framed for wealthier wives by specifying that property could only be acquired by "gift, grant, purchase, inheritance, devise, or bequest." Women with no real estate and little personalty did not gain much from the 1877 statute. Wives gained control of their wages in 1887, but as there were relatively few working wives in Virginia at this time, the provisions affected only a small percentage of married women. For those women who did operate businesses, however, legislative easing of coverture restrictions must have been a great boon.

While again the connection is not clear without more research, it is possible that legislative changes in married women's property law contributed to the organization and 
vitality of the Virginia women's suffrage movement in the first decade of the twentieth century. Basch notes this connection in New York, explaining: 209

The drive for married women's property rights provided [New York women] with a perfect bridge, permitting the cautious to remain on the domestic side, the intrepid to invade the political side, and some to move gradually from one to the other. Organizing for an improvement in the legal status of wives was an important precursor of the independent, post-Civil War [suffrage movement].

Virginia suffragists were quick to note that they owned taxable property, and suffered like their forefathers under taxation without representation. 210

Just as it is important not to deemphasize the beneficial effects of the married women's property acts, it is also important not to exaggerate them. Many legislators enacted the laws because it was expedient to do so. Rights for all women in Virginia -- married and single -- came slowly and grudgingly. Tracts proscribing the role of women, and warning against women's suffrage, enjoyed wide circulation in late nineteenth and early twentieth-century Virginia. Dr.W.W. Parker, a former president of the Medical Society of Virginia, published a book in 1892 with the descriptive title Woman's Place in the Christian World: Superior Morally. Inferior Mentally, to Man -- Not oualified for Medicine or Law -- The contraeity and Harmony of the sexes. Parker claimed that there was a physiological basis for woman's intellectual inferiority: her brain was lighter and blood was directed to the sensory rather than the thinking parts of the brain. 211 
Several decades later, a lawyer named Conway Sams published a long diatribe against women's suffrage entitled shąl Women Vote?. In 1920, the Virginia General Assembly answered Sams' question with a resounding no by refusing to pass the nineteenth amendment to the United States Constitution.

In her book about the free women of antebellum Petersburg, Virginia, Suzanne Lebsock successfully refutes previous studies which had presented the life of the antebellum Southern women as narrow and circumscribed. The idea of the Civil War as a watershed for Southern women, Lebsock argues, must be modified in light of the evidence she presents. At the close of her book, Lebsock speculates that the other side of the Civil war as watershed argument -- that lives of Confederate women steadily improved as a result of the war experience -- must be rethought as well. Lebsock contends that the war itself was in several respects a setback for the free women of Virginia. She proposes a tentative conclusion: there may have been some progress for Southern women after the war, but progress in the North outstripped that in the South. Lebsock emphasizes the fact that her suppositions are based on slim evidence, however, and suggests that the weakness of organized feminism in the late nineteenth-century South might not be a good predictor of women's status. As in Petersburg before the war, the woman in postbellum Virginia might have assumed power "as long as she did not ask that it be made obvious, offical, or general." 212 
The preliminary evidence offered in this paper provides a few responses to Lebsock's speculations. While the Civil War might have resulted in immediate economic losses for Virginia women, in the long run the war did lead to positive change for women, particularly wives, in the state. It is difficult to prove that the experience of the Civil War directly changed the attitudes of men toward married women in Virginia. Yet contemporary figures such as senator Charles Smith attributed the need for alterations in coverture to the altered position of wives in Virginia as a result of the war. Ironically, the war might also have benefitted women by creating an atmosphere conducive to debt relief legislation, which contributed to the passage of the first Virginia married women's statute. In any case, rather than the suppression of women by defeated men which Lebsock feared might be revealed in a study of postwar Virginia, there seems to have been a steadily growing respect among the men of the Commonwealth for the capabilities of women. This respect was not limited to the domestic sphere: married women's power in the public domain was acknowledged by the legislature, the courts, and the commercial world. By 1900, the feme covert in Virginia had achieved a separate identity. 
ENDNOTES

1. See, e.g., Norma Basch, In the Eyes of the law: Women, Marriage, and Property in Nineteenth-Century New York (Ithaca, NY: Cornell University Press, 1982); Richard Chused, "Married Women's Property Law: 1800-1850," Georgetown University Law Review 71 (1983), pp. 13591425; Suzanne Lebsock, "Radical Reconstruction and the Property Rights of Southern Women," The Journal of. Southern History 43 (1977), pp. 195-216.

2. For a detailed discussion of the origins and rules of coverture, see Basch, Eyes, pp. 42-69; and Leo Kanowitz, Women and the Law: The Unfinished Revolution (Albuquerque: The University of New Mexico Press, 1969), pp. 35-40.

3. See Basch, pp. 64-66, for a description of equity and the married women's estate.

4. Linda Kerber, Women of the Republic: Intellect and Ideology in Revolutionary America. (Chapel Hill: The University of North Carolina Press, 1980), pp. 152-3.

5. For different views of the colonial wife's position under the law, see Richard B. Morris, studies in the History of American Law with Special References to the. 17th and 18th centuries, 2nd ed. (Philadelphia: Joseph M. Mitchell, Co., 1959), pp. 126-200; Marylynn Salmon, "Equality or Submersion? Eeme Covert status in Early Pennsylvania" in Carol Ruth Berkin and Mary Beth Norton (eds.), Women of America: A History (Boston: Houghton Mifflin Company, 1979), pp. 93-113; Salmon, "Women and Property in South Carolina: The Evidence From Marriage Settlements, 1770-1830," William and Mary. Quarterly 39 (1982), pp. 655-685; Joan R. Gunderson and Gwen Victor Campbell, "Married Women's Legal status in Eighteenth Century Virginia and New York, "William and Mary Ouarterly 39 (1982), pp. 114-134; Chused, "property," pp. 1389-1397; and Basch, pp. 22-25.

6. Chused, "Property," pp. 1405-1409.

7. Ibid., pp. 1269-1372.

8. For the text of the 1848 New York statute, see Basch, p. 233 .

9. John D. Johnston, Jr., "Sex and Property: The Common Law Tradition, the Law School Curriculum, and Developments Toward Equality," New York University Law Reyiew 47 
(1972), pp. 1061, 62 .

10. See Peggy A. Rabkin, Eathers to Daughters: The Legal Foundations of Female Emancipation (Westport, CT: Greenwood Press, 1980), pp. 74-124 and generally.

11. Basch, pp. 113-135.

12. Chused, pp. 1397-1412.

13. Basch, p. 114 .

14. Chused, p. 1398.

15. See Basch, p. 202, n. 2, citing sources.

16. In "Husband and Wife -- Memorandum on the Mississippi Woman's Law of 1839," Michigan Law Review XLII (1944), pp. 1110-21, Elizabeth G. Brown suggests that

Mississippi's proximity to Louisiana influenced the early passage of the Mississippi married women's law.

17. Chused, p. 1403; see especially n. 233.

18. Journal of the House of Delegates of the state of Virginia, 1848-1849, p. 50 .

19. Ibid., p. 280,463 .

20. Ibid., p. 557, 559.

21. Although legislative bills are not available for this period, the Richmond whig printed the text of the committee bill in the July 16,1849 issue.

22. House Journal, 1848-49, p. 571 .

23. Ibid., p. 586-89.

24. Richmond Whig, July 16, 1849.

25. Peter Coleman, Debtors and Creditors in America: Insolvency. Imprisonment for Debt and Bankruptcy. 1607-1900 (Madison: State Historical Society of Wisconsin, 1974), p. 191 .

26. Basch, p. 122-126; see, e.g., Acts of Assembly of the Commonwealth of Virginia, 1836-7, p. 47 (property of intestate insolvent exempted for relief of widows and children); Acts, 1841-42, p. 54 (stay law of 1837 revived through 1843).

27. Richmond whig, July 16, 1849. 
28. W. Hamilton Bryson, "Abolition of the Forms of Action in Virginia," University of Richmond Law Review 17 (1983), pp. 273-284.

29. Bertram Wyatt-Brown, Southern Honor: Ethics and Behavior in the old South (New York: Oxford University Press, 1982), p. 262 .

30. Suzanne Lebsock, The Eree Women of Petersburg: Stantus and culture in a southern Towne 1784-1860 (New York: W.W. Norton and Company, 1984), p. 60 .

31. Ibid, pp. 57-58, 61-67.

32. Basch, p. 114 .

33. See, e.g., Ibid., pp. 124-5.

34. See Lebsock, Petersburg; Catherine Clinton, The Rlantation Mistress: Woman's World in the old south (New York: Pantheon Books, 1982); Jane Turner Censer, North Carolina Planters and Their Children, 1800-1860. (Baton Rouge: Louisiana State University Press, 1984).

35. Lebsock, Retersburg, p. 69.

36. Acts, 1831-32, p. 27 .

37. Acts, 1845-46, p. 116 .

38. Journal of the senate of the commonwealth of Virginia, 1857-8, p. 241.

39. Ann Firor Scott, The Southern Lady: From Pedestal to Politics, 1830-1930. (Chicago: The University of Chicago Press, 1970), p. 21 .

40. Lebsock, Petersburg, p. 236.

41. Richmend Whige July $16,1849$.

42. The several married women's resolutions and bills which were introduced in the General Assembly in the 1850's received scant attention. See, e.g., House Journal, 1855-56, pp. 101, 112 .

43. Virginia, Debates and Rroceedings of the Constitutional Convention, 1867-68 (Richmond, 1868), pp. 58-59.

44. Ibid., pp. 554-55.

45. James Douglas Smith, "The Virginia Constitutional Convention of 1867-1868," (unpublished M.A. thesis, University of Virginia, 1956), p. 83, n. 52 . 
46. Richard C. Hume, "The Membership of the Constitutional Convention of 1867-68: A Study in the Beginnings of Congressional Reconstruction in the Upper South," Virginia Magazine of History and Biography 86 (1978), p. 481; Richard G. Lowe, "Virginia's Reconstruction Convention: General Schofield Rates the Delegates," VMTB 80 (1972), p. 350 .

47. Hume, "Membership," p. 481; Lowe, "Reconstruction," p. 348 .

48. The text of the bill is printed in the Richmond Dispatch, April 14, 1868 .

49. Ibid.

50. Lebsock, "Reconstruction," pp. 200-204.

51. Ibid, p. 198.

52. Ibid, p. 202 .

53. Ibid., p. 204-207.

54. Virginius Dabney, Virginia: The New Dominion (New York: Doubleday and Company, Inc., 1971), p. 353.

55. James Douglas Smith, "Virginia During Reconstruction," (unpublished Ph.D. dissertation, University of Virginia, $1960)$, p. 115 .

56. Hume, "Membership," p. 470.

57. Senate Journal, 1874 , pp. 419, 429.

58. Acts, 1874-75, pp. 442-43.

59. Senate Journal, 1874-75, pp. 58-59; House Journal, $1874-75$, p. 260 .

60. Senate Journal, 1876-77, pp. 273-274; House Journal, 1876-77, pp. 494-5; Acts, 1876-77, pp. 333-4.

61. Acts, 1876-77, pp. 333-34.

62. Basch, p. 114 .

63. Charles T. Smith, Property Rights of Married Women

(Richmond: James E. Goode, 1877), p. 6 .

64. Acts, $1869-70$, p. $162 ; 1870-71$, p. 148 .

65. 22 Gratt. $266,279-301$ (1872). 
66. Acts, 1871-72, p. 72 .

67. Acts, 1872-73, p. 177.

68. Code of Virginia, 1873, Chapter 184. See also Edward L. Ryan, "Imprisonment for Debt: Its Origin and Repeal," УMHB 42 (1934), p. 53-58.

69. Acts, 1876-77, p. $213 ; 1877-78$, p. 239.

70. See Smith, "Virginia During Reconstruction," pp. 165-194; Jack P. Maddex, The Virginia Conservatives, 1867-1879. (Chapel Hill: The University of North Carolina Press, 1970), pp. 165-183; and Allen Moger, Virginia:

Bourbonism to Byrd, 1879-1925. (Charlottesville: The University Press of Virginia, 1968), pp. 76-94 for detailed descriptions of economic conditions in postwar Virginia.

71. Smith, "Reconstruction," p. 180.

72. Senate Journale 1869-70, pp. 45-46.

73. Charles T. Smith, Broadside, Address to the People of Amherst and Nelson Counties, 1877, Alderman Library, University of Virginia, Charlottesville, Virginia.

74. Ryan, "Debt," p. 54.

75. Chused, pp. 1403-04.

76. Ibid., p. 1425 .

77. Basch, p. 122 .

78. See Carol Jean Clare, "The Woman Suffrage Movement in Virginia: Its Nature, Rationale and Tactics" (unpublished M.A. thesis, University of Virginia, 1968), for a review of the women's movement (or lack thereof) in late 19 th-century Virginia.

79. Smith, Rroperty Rights, p. 13.

80. See Basch, pp. 115-19, for an analysis of Hertell's speech before the New York legislature.

81. Smith, Rroperty Rights, pp. 6, 8 .

82. Senate Journal, 1879-80, pp. 336-37.

83. Acts, 1878-79, pp. 353-54.

84. Jamil S. Zainaldin, "The Emergence of a Modern American Family Law: Child Custody, Adoption, and the Courts." 
Northwestern University Law Reyiew 73 (1979), pp. 1068-1074.

85. Wyatt-Brown, Southern Honor, p. 243 .

86. Acts, 1871-72, p. 418-419.

87. Senate Journal, 1874, p. 233; 1875-76, p. 93.

88. Lebsock, Retersburg; Clinton, Rlantation Mistress;

Jonathan M. Weiner, "Female Planters and Planters' Wives in Civil War and Reconstruction: Alabama, 1850-1870," Alabama Review 3 (1977), pp. 135-149.

89. Smith, property Rights, p. 4 .

90. Educational Journal 10 (May, 1879), p. 213.

91. Martin P. Burks, Notes on the Property Rights of Married Women in Virginia (Lynchburg, VA: J.P. Bell Company, 1894), pp. 11-12.

92. Smith, Property Rights, p. 14 .

93. Lebsock, "Reconstruction,", p. 216.

94. See Paul Gaston, The New South Creed (New York: Alfred A. Knopf, 1970), pp. 153-186 and generally.

95. Maddex, Conservatives, p. 276.

96. James Tice Moore, Two Paths to the New South: The Virginia Debt Controversy, 1870-1883. (Lexington: The University Press of Rentucky, 1974), p. 39.

97. Educational Journal 10 (May 1879), p. 213.

98. Charles Smith, Broadside.

99. Smith, Property Rights, p. 14 .

100. Ibid.

101. Lebsock, "Reconstruction," p. 200.

102. Richmond State, April 4, 1877; Richmond Dispatch, April 4, 1877; Shenandoah Valley, April 20, 1877; Norfolk Virginian, April 6, 1877. See also The Loudon Mirror, April 12, 1877.

103. Virginia Law Journal. [hereafter VLJ] 4 (1880), pp. 65, 73-74.

104. Ibid., pp. 74-75. 
105. VuJ 5 (1881), pp. 139-140.

106. See Holly Beth Fitzsimmons, "The Law and the Reasons Thereof: John B. Minor and Legal Education at the University of Virginia, 1845- 1895" (unpublished M.A. thesis, University of Virginia, 1976) for an analysis of Minor's teaching and influence.

107. 6LJ 7 (1883), pp. 636-38.

108. John Ritchie, The Eirst Hundred Years: A Short History of the School of $\mathrm{Law}$ of the University of Virginia for the Period 1826-1926 (Charlottesville: The University Press of Virginia, 1978), p. 38 .

109. See Raymond Pulley, eld Virginia Restored: An Interpretation of the Rrogressive Impulse, 1870-1930 (Charlottesville: The University Press of Virginia, 1968), pp. 4-5 and generally.

110. Speech by John Randolph Tucker, Report of the Third Annual Meeting of the Virainia state Bar Association (Richmond, VA: Everett Waddey Co., 1891) p. 210.

111. Virginia Law Register [hereafter VLR] 1 (1895), p. 480 .

112. 15 (1891), p. 683 .

113. See Peggy Rabkin, "The Origins of Law Reform: The Social Significance of the Nineteenth-Century Codification Movement and its Contribution to the Passage of the Early Married Woman's Property Acts," Buffale Law Reyiew 24 (1974-75), pp. 683-760 for a discussion of the democratic significance of the codification movement.

114. Moore, Two Raths, pp. 24-25.

115. Both Scott, Southern Lady, p. 168 and Lebsock, Petersburg, pp. 247-8 hint at a postwar backlash against women's rights among some men in the South.

116. VIJ 10 (1886), pp. 65-7.

117. $\mathrm{VLJ} 11$ (1887), p. 66; 14 (1890), pp. 537-47.

118. VuJ 14, pp. 546-7; 12 (1888), pp. 143-4 .

119. VuJ $14(1890)$, pp. 538-40.

120. Lyon Tyler, Men of Mark in Virginia (Washington, DC: Men of Mark Publishing Company, 1906), pp. 291, 300.

121. Gaston, New South, p. 48. 
122. VLJ 10 (1886), p. 69 .

123. Report of the First Annual Meeting of the VSBA (1889), pp. 32-33.

124. See, e.g., Report of the Second Annual Meeting of the VSBA (1890), p. 32-33; Report of the Third Annual Meeting (1891), pp. 27-36.

125. Gaston, New South, pp. 159-160.

126. VLJ 13 (1889), p. 678.

127. Maddex, Conservatives, p. 290.

128. VLJ 1 (1877), pp. 65-6.

129. VLJ 4 (1880), p. 711.

130. VLJ 3 (1879), pp. 73-75.

131. VLJ 10 (1886), pp. 386-7.

132. See, e.g., Report of the Third Annual Meeting of The VSBA (1891), p. 36. Virginia lawyers resembled other Virginians who partook in "a confused and sometimes pathetic effort to participate in the new southern departure of rapid industrialization, while at the same time attempting to salvage and resurrect the best traditions of old Virginia." Pulley, old Virginia, p. 24 .

133. See, e.g., Johnston, "Sex and Property,", p. 1069. Basch, however, manages to overlay a framework on the course of married women's law in New York state. Reviewing appellate cases decided between 1848 and 1888, Basch maintains that judges limited the effect of the statutes in three ways -- by ruling sections unconstitutional, by applying equity precedents in construction, and most important, by adhering strictly to the common law fiction of marital unity. Basch, pp. 200-223.

134. From 1877 to the enactment of the 1887 Code, the Virginia General Assembly passed just one law regarding married women's property rights, a minor 1878 amendment to the Smith Act. Acts, 1877-78, p. 247-8. Members of the General Assembly did continue to propose married women's bills in the decade after 1877, suggesting that at least a few Virginia legislators felt that the 1877 act did not adequately establish or protect the property rights of married women. See, e.g., Senate Journal, 1883-84, pp. 245,305 .

135. Breeding $y_{2}$ Dayis, 77 Virginia 639, 649 (1883). 
136. Ibid. at 650-651.

137. VLJ 7 (1883), pp. 636-637.

138. Browne y. Bockover, 84 Va 424 (1888).

139. Williams_V._Lord and Robinson, 75 Va 390,397 (1881).

140. N. and_W. R.R._e._V._Prindle and_Wife, 82 Va 122 (1886).

141. Ibjd. at $130,133$.

142. Yates_y. Law, 86 Va 117 (1889).

143. Hayes_and_Wife $v$ e Mutual_Protection_Association, $76 \mathrm{Va}$ $225,229-230$ (1882).

144. Ibid. at 229.

145. Earley V. Tillare 81 Va 275 (1886).

146. Rrindle, p. 126.

147. Crabtree V. Dunn, 86 Va 953 (1890).

148. Alexander_ $y$,_Alexander, 85 Va 353,366-7, 371 (1888).

149. Crockett $\mathrm{v}$. Doriot, 85 Va 240 (1887).

150. McDonald and Wife $v$. Hurst, Purnell and Company, $86 \mathrm{Va}$ 885 (1890).

151. VLJ 3 (1879), pp. 74, 194; 12 (1888), pp. 145, 149.

152. VLJ 3 (1879), p. 196.

153. VLJ 10 (1886), pp. 386-88.

154. Ibid., p. 386-7.

155. VLJ 10 (1886)，pp. 513-15.

156. VLJ 4 (1880), p. 710 .

157. Ibid., p. 72.

158. VLJ 3 (1879), pp. 3, 74-75.

159. Ibid., p. 202.

160. VLJ., p. 385. 
161. G. Edward White, Tort Law in America: An Intellectual History (New York: Oxford University Press, 1980), p. 40 .

162. See, e.g., Lebsock, "Reconstruction," p. 215.

163. Acts, 1883-84, pp. 702-703.

164. Third Annual Meeting of the VSBA (1891), p. 120.

165. Code of Virginia, 1887, Section 2284.

166. Ibid., Section 2287.

167. Angela Bongiorno in "White Women and Work in Richmond, Virginia, 1870-1874" (unpublished master's thesis, University of Virginia, 1978), p. 61, estimates that 148 of the Richmond female workforce in 1880 was married -no doubt a great majority of this number was black.

168. code 1887, Section 2287.

169. Ibid., Sections 2288, 2297, 2295.

170. Ibid., Sections 2293, 2286, 2296.

171. Ibid., Sections 2294, 2297.

172. Third Annual Meeting of the VSBA, pp. 124-25.

173. Burks, Notes, p. 83, Code 1887, Section 2290.

174. Third Annual Meeting of the VSBA, p. 123.

175. See, e.g., VhJ 11 (1887), p. 1; 12 (1888), pp. 142-3.

176. Third Annual Meeting of the VSBA, p. 121.

177. Burks, Notes, p. 11; see also William Minor Lile, "An Analysis of Chapter 103 of the Virginia Code Creating and Regulating the Separate Estate of Married Woman, " in VLR 4 (1898-99), pp. 413-439.

178. Acts, 1899-1900, pp. 1240-1.

179. Norfolk and Western $B . R, C e, V e$ Dougherty and Wife, 92 Va 372 (1895).

180. Richmond Railway and Electric Ce. $\mathrm{V}$. Bowles, $92 \mathrm{Va}$ 738,741 (1896).

181. VLR 2 (1896-97), p. 20.

182. Dezendorf $\mathrm{V}$. Humphreys, 95 Va 473,477 (1898). 
183. Bowles at 774-5.

184. VLB 2 (1896-97), p. 20 .

185. VLR 5 (1899-1900), p. 339.

186. Burks, Notes, p. 63.

187. VLR 1 (1895-1896), pp. 356-7.

188. VLR 3 (1897-98), pp. 635-644.

189. Ibid., pp. 797-802.

190. VLR 4 (1898-99), pp. 468, 536-7.

191. Eleventh_Annual_Meeting_of the_VSBA (1899), pp. 252-3, and generally, pp. 251-6.

192. VLR 5 (1899-1900), p. 339-41.

193. Hirth V. Hirth, 98 Va 121 (1900).

194. VLR 5 (1899-1900), p. 775.

195. Acts, 1899-1900, pp. 1240-1. There was apparently no constitutional challenge to the retroactive provisions of the 1900 act. VLB $6(1900-01)$, p. 488 .

196. Basch, p. 225.

197. See Chused, p. 1412.

198. Acts, 1893-94, p. 722-23.

199. Geiger V._Blackley, 86 Va 328,332 (1889).

200. Third Annual Meeting of the VSBA, p. 125.

201. Owens ve Owens, 96 Va 191, 196 (1898).

202. Acts, 1891-92, p. 333 .

203. Ibid., pp. 391-92.

204. Acts, 1895-96, p. 486-487.

205. Acts, 1897-98, p. 744 .

206. VLB 6 (1900-01), p. 52 .

207. Ibid., pp. 52-3. 
208. Jane Turner Censer, "'Smiling Through Her Tears': Antebellum Southern Women and Divorce," The American Jolurnal_of_Legal_History 25 (1981), p. 40 .

209. Basch, p. 164

210. See, e.g., speech of Orra Langhorne reported in the Bichmond Times, January 30, 1894; Lloyd C. Taylor, Jr., "Lila Meade Valentine: The FFV as Reformer," VMHB 70 (1962), p. 483 .

211. W. W. Parker, Woman's Place in the christian World: Superior_Morally. Inferior Mentally, to Man (Richmond, VA: J.W. Fergusson and Son, 1892), pp. 11-12.

212. See Lebsock, Retersburg, p. 244-49. 


\section{BIBLIOGRAPHY}

\section{RRIMARY MATERIALS}

\section{Documents}

Acts of Assembly, Commonwealth of Virginia, 1830-1900 Journal of the senate of the Commonwealth of Virginia, 1830-1900

Journal of the House of Delegates of the state of Virginia, 1830-1900

Debates and Proceedings of the Constitutional Convention of Virginia, 1867-68

\section{Newspapers and Periodicals}

Loudon Mirror

Norfolk Virginian

Richmond Dispatch

Richmond state

Richmond Times

Richmond whig

The Shenandoah Valley

Virginia Educational Journal

\section{Legal Materials.}

Virginia Reports, 1877-1900

Virginia Law Journal, 1877-1893

Virginia Law Register, 1895-1901

Reports of the Annual Meetings of the Virginia state Bar Association, 1889-1901

\section{Nineteenth Century Published Materials}

Burks, Martin P. Notes on the Property Rights of Married. Women in Virginia, Lynchburg, VA: J.P. Bell Company, 1894 .

Parker, W.W. Woman's Place in the Christian World:

Superior Morally, Inferior Mentally, to Man. Richmond, VA: J.W. Fergusson and Son, 1892 .

Smith, Charles T. Broadside, Address to the People of Augusta and Nelson Counties, 1877. Alderman Library, University of Virginia, Charlottesville, Virginia. 


\section{SECONDARY SOURCES}

\section{Unpublished_Studies}

Bongiorno, Angela. "White Women and Work in Richmond, Virginia, 1870-1884." (M.A. thesis, University of Virginia, 1978).

Clare, Carol Jean. "The Woman Suffrage Movement in Virginia. Its Nature, Rationale and Tactics." (M.A. thesis, University of Virginia, 1968).

Fitzsimmons, Holly Beth. "The Law and the Reasons Thereof: John B. Minor and Legal Education at the University of Virginia, 1845-1895." (M.A. thesis, University of Virginia, 1976.

Smith, James Douglas. "The Virginia Constitutional Convention of 1867-1868." (M.A. thesis, University of Virginia, 1956).

"Virginia During Reconstruction." (Ph.D. dissertation, University of Virginia, 1960).

\section{Published studies}

Basch, Norma. In the Eyes of the Law: Women. Marriage. and Property in Nineteenth-Century New York. Ithaca, NY: Cornell University Press, 1982.

Brown, Elizabeth G. "Husband and Wife -- Memorandum on the Mississippi Woman's Law of 1839." Michigan Law Review XLII (June 1944), 1110-21.

Bryson, W. Hamilton. "Abolition of the Forms of Action in Virginia." University of Richmond Law Review 17 $(1983), 273-284$.

Censer, Jane Turner. "'Smiling Through Her Tears': Antebellum Southern Women and Divorce," The American Journal of Legal History 25 (January 1981), 24-42.

Clinton, Catherine. The Plantation Mistress: Woman's World in the old south, New York: Pantheon Books, 1982.

Coleman, Peter J. Debtors and Creditors in Americai: Insolyency, Imprisonment for Debt, and Bankruptcy. 1607-1900. Madison: State Historical Society of Wisconsin, 1974 .

Chused, Richard. "Married Women's Property Law: 18001850." Georgetown University Law Review 71 (1983), $1359-1425$. 
Dabney, Virginius. Virginia: The New Dominion. New York: Doubleday and Company, Inc., 1971.

Gaston, Paul. The New South creed. New York: Alfred A. Knopf, 1970 .

Gunderson, Joan R. and Campbell, Gwen Victor. "Married Women's Legal status in Eighteenth Century Virginia and New York." William and Mary Quarterly 39 (1982), 114-134.

Hume, Richard C. "The Membership of the Constitutional Convention of 1867-68: A study in the Beginnings of Congressional Reconstruction in the Upper South." Virginia Magazine of History and Biography 86 (1978), 461-484.

Johnston, John D., Jr. "Sex and Property: The Common Law Tradition, The Law School Curriculum and Developments Toward Equality." New York University Iaw Reyiew 47 (1972), 1033-93.

Kanowitz, Leo. Women and the Law: The Unfinished Reyolution. Albuquerque: University of New Mexico Press, 1969.

Kerber, Linda. Women and the Republic: Intellect and Ideology in Revolutionary America. Chapel Hill: The University of North Carolina Press, 1980.

Lebsock, Suzanne D. "A Share of Honour": Virginia Women 1600-1945. Richmond: Virginia Women's Cultural History Project, 1984 .

The Eree Women of Petersburg: Status and culture in a southern Town, 1784-1860. New York: W.W. Norton and Company, 1984.

- "Radical Reconstruction and the Property

Rights of Southern Women." The Journal of Southern History 43 (1977, 195-216.

Lowe, Richard G. "Virginia's Reconstruction Convention: General Schofield Rates the Delegates." Virginia Magazine of History and Biography 80 (1972), 341-360.

Maddex, Jack P. The Virginia Conservatives, 1867-1872. Chapel Hill: The University of North Carolina Press, 1970.

Moger, Allen W. Virginia: Bourbonism to Byrd, 1870-1925. Charlottesville: The University Press of Virginia, 1968.

Moore, James T. Two Paths to the New South: The Virginia Debt controversy, 1870-1883, Lexington: The University Press of Rentucky, 1974 . 
Morris, Richard B. Studies in the History of American Law with special References to the lith and l8th centuries, 2nd edition. Philadephia: Joseph M. Mitchell Co., 1959.

Morris, Thomas R. The Virginia supreme court: An Institutional and Political Analysis. Charlottesville: The University Press of Virginia, 1975.

Pulley, Richard. old Virginia Restored: An Interpretation of the Progressive Impulse, 1870-1930. Charlottesville: The University Press of Virginia, 1968.

Rabkin, Peggy A. Eathers to Daughters: The Legal Eoundations of Eemale Emancipation. Westport, CT: Greenwood Press, 1980 .

Rabkin, Peggy A. "The Origins of Law Reform: The Social Significance of the Nineteenth-Century Codification Movement and Its Contribution to the Passage of the Early Married Women's Property Acts." Buffale Law Reyiew 24 (1974-75), 683-760.

Ritchie, John. The First Hundred Years: A Short History of the School of Law of the University of Virginia for the Period 1826-1926. Charlottesville: The University Press of Virginia, 1978.

Ryan, Edward. "Imprisonment for Debt: Its origin and Repeal," Virginia Magazine of Historv and Biography 42 (1934) 53-58.

Sachs, Albie and Wilson, Joan Hoff. Sexism and the Law. New York: The Free Press, 1978.

Salmon, Marylynn. "Equality or Submersion? Eeme covert Status in Early Pennsylvania" in Berkin, Carol R. and Norton, Mary Beth (eds.), Women of America: A History (Boston: Houghton Mifflin Company, 1979), 95-113.

The Evidence from Marriage Settlements, 1770-1830," William and Mary Ouarterly 39 (1982), 655-685.

Scott, Ann Firor. The Southern Lady: From Pedestal to Politics, 1830-1930. Chicago: The University of Chicago Press, 1970.

Taylor, Lloyd C., Jr. "Lila Meade Valentine: The FFV as Reformer." The Virginia Magazine of History and Biography 70 (1962), 471-487. 
Tyler, Lyon. Men of Mark in Virginia. Washington, DC: Men of Mark Publishing Company, 1906.

Weiner. Jonathan M. "Female Planters and Planters' Wives in Civil War and Reconstruction: Alabama, 1850-1870." The Alabama Reyiew 3 (1977), 135-149.

White, G. Edward. Tort Law in America: An Intellectual History. New York: Oxford University Press, 1980.

Wilson, Joan Hoff, "Hidden Riches: Legal Records and Women, 1750-1825," in Kelley, Mary (ed.), Woman's Being, Woman's Place: Female Identity and Vocation in American History.

(Boston: G.R. Hall and Company, 1979), 7-25.

Wyatt-Brown, Bertram. Southern Honor: Ethics and Behayior in the old south. New York: Oxford University Press, 1982.

Zainaldin, Jamil s. "The Emergence of a Modern American Family Law: Child Custody, Adoption, and the Courts." Northwestern University Law Reyiew 73 (1979), 1038-89. 